University of Nebraska - Lincoln

DigitalCommons@University of Nebraska - Lincoln

$12-1947$

\title{
A Preliminary Study of a Physical Basis of Bird Navigation
}

Henry L. Yeagley

Pennsylvania State University

Follow this and additional works at: https://digitalcommons.unl.edu/biosciornithology

Part of the Ornithology Commons

Yeagley, Henry L., "A Preliminary Study of a Physical Basis of Bird Navigation" (1947). Papers in Ornithology. 54.

https://digitalcommons.unl.edu/biosciornithology/54

This Article is brought to you for free and open access by the Papers in the Biological Sciences at DigitalCommons@University of Nebraska - Lincoln. It has been accepted for inclusion in Papers in Ornithology by an authorized administrator of DigitalCommons@University of Nebraska - Lincoln. 


\title{
Journa 1 \\ of \\ Applied Physies
}

Volume 18, Number 12

December, 1947

\section{A Preliminary Study of a Physical Basis of Bird Navigation}

\author{
Henry L. Yeagley \\ Department of Physics, The Pennsylvania State College, State College, Pennsylvania
}

(Received June 26, 1947)

Foreword

F. C. WhITMORE

Dean of the School of Chemistry and Physics, The Pennsylvania State College

The theory presented was formulated in 1942 at the Pennsylvania State College by Dr. H. L. Yeagley, Associate Professor of Physics. Its only public presentation is in a preliminary non-technical article in the October 1943 issue of The Penn State Engineer, a local student publication. The training of birds for the first experiments was begun in May 1943. The first actual field test was made November 7, 1943 with homing pigeons trained to navigate to Paoli, Pennsylvania. This experiment was witnessed by officers of the U. S. Army Signal Corps, including Major Otto Meyer, in charge of the Army Pigeon Service Agency of the U. S. Army Signal Corps. Because of the positive nature of the results and their importance to communication in the war, all subsequent work was reported only to the Army Service Forces:

Report on Bird Navigation, "Theory and confirming evidence" Decemder 12, 1944.

Report on Bird Navigation, "Hamlet experiment," April 24, 1945.

Report on Bird Navigation, "A continuation of experiments started at the Pennsylvania State College in December, 1942," January 4, 1946.

Report on Bird Navigation, "East-West experiment," June 30, 1946.

The bird navigation theory as presented implies an organ or organs in the bird's physiology which are sensitive to the effect of its motion through the vertical component of the earth's magnetic field and to the effort exerted to overcome the coriolis force, due to the earth's rotation. Both these influences involve a set of lines which together form a navigational gridwork. By correlating its instantaneous land speed with the two above effects, a bird can fly to its home which is a unique point in this gridwork, or to related companion points existing in the gridwork at positions other than its home. Experimentation with homing pigeons between the home and spurious home points (conjugate or companion points) has yielded data which supports the theory.

$\mathrm{P}$

ROBABLY no natural phenomenon has intrigued man and held his interest more than the ability of the homing pigeon to fly long distances from a strange locality and across unfamiliar territory to its home loft. Many leading ornithologists believe that this same ability guides wild birds in their long migratory flights over land and water areas. Invariably, references made to this remarkable accomplishment in the bird world are in terms of "instinct," which is a way of saying "we don't know."

The over-all problem of bird navigation involves at least the following five factors:

1. A desire on the part of the homing pigeon 
to go to the home loft or, in the case of wild birds, to go to their summer feeding and breeding grounds, or their warmer wintering areas during migratory periods.

2. The physical strength and endurance to fly the required distance.

3. A knowledge of familiar landmarks, within a minimum radius, for piloting to the exact spot. (This radius distance for homing pigeons is known to be about twenty-five miles.)

4. The ability to navigate. This implies the possession and use of an organ or organs as navigating instruments.

5. Considerable navigating experience in flying in and about the "home" region. With homing pigeons this experience is artificially built up by sending the birds to gradually increasing distances.

It is well known that many birds of the migratory species return to their breeding and nesting grounds after being trapped and sent hundreds of miles into strange territory. Many such flights have been arranged so that the birds must orient themselves and fly hundreds of miles over water routes out of sight of land. One species, the Golden Plover, ${ }^{1}$ performs the remarkable feat of navigating 3000 miles from Alaska to the Hawaiian Islands with no landmarks over the broad expanses of the Pacific Ocean. Hundreds of individuals of the albatross family roam over thousands of square miles of the Southern $\mathrm{Pa}$ cific area. Members of each species finally return to their own tiny island to breed and raise young. Hood Island ${ }^{2}$ of the Galapagos Archipelago group, is headquarters for one species of these birds. Since there are no "sign posts" of any kind over the ocean wastes, the flights must involve true navigation until the home island comes into view. Other types of birds, including noddy and sooty terns, swallows, herring gulls, numerous varieties of ducks, hawks, storks, starlings, chimney swifts, have the homing or navigating ability developed to a high degree.

Thus, while man has been slowly and laboriously learning to navigate during the past six

\footnotetext{
1 Frederick C. Lincoln, The Migration of American Birds (Doubleday, Doran and Company, Inc., Garden City, New York, 1936).

${ }^{2}$ J. L. Peters, Check-list of Birds of the World (Harvard University Press, Cambridge, Massachusetts, 1931), Vol. 1 or 2; ibid., Vol. 2, 1937; ibid., Vol. 3, 1940; ibid., Vol. 4.
}

centuries, birds have been using a system of their own for perhaps millions of years.

Hundreds of papers have been written suggesting possible fragmentary explanations of the mystery of bird orientation. The more scientifically possible of these explanations involve sensitivity of the bird to one or more of the following:

1. The effect of motion through the earth's magnetic field. ${ }^{3}$

2. Gravitational differences due to variations in the earth's radius.

3. The Coriolis effect due to the earth's rotation. ${ }^{4}$

In order to set up a working system of bird navigation or, indeed, of any navigation, a combination of two or more overlapping fields of influence is necessary. Each of these must possess definite gradients. Possible grid patterns might represent repetitive, displaced fields of a single kind, or combinations of two or more of the following :

1. Light beams-limited, by horizon extinction, to comparatively small areas, and useful only in piloting.

2. Sound beams-too limited for long distances, conceivably available only for piloting.

3. Electric fields-extremely limited by small intensity factor, variable magnitudes, lack of permanence.

4. Electromagnetic radiations-network of radio or radar beams such as are used in the radiorange network system of navigation or, more properly, piloting.

5. Magnetic fields-the earth's natural magnetic field, a somewhat irregular function of distance from the magnetic poles.

6. Force fields, such as:
a. Coriolis force,
b. Gravitational force,
c. Centrifugal force.

${ }^{3}$ C. Viguier, "Le seus de l'orientation," Rev. Phil. 14, 1 (1882); A. Thauzies, "Apropos d'une theorie sur l'orientation du pigeon voyageur," Rev. Sci. (series 5) 3, 270 (1905); "L'orientation du pigeon voyageur," Ann. Med. Vet. 54, 141 (1905).

"Dr. W. H. Thorpe and D. H. Wilkinson, "Ising's theory of bird orientation," Nature, December 21 (1946). Also, G. Ising, "The physical possibility of a biological sense of orientation based on the rotation of the earth," Ark. Math. Astrophys. 32A, No. 4 (1946). 
Appended is a bibliography of the fragmentary suggestions that have previously been made in explanation of bird navigation. Special attention is called to Dr. D. R. Griffin's paper,* "The sensory basis of bird navigation," and to W. M. Levi's book, The Pigeon, $\dagger$ for an excellent general coverage of the subject.

In setting up the present theory of bird navigation the following well-known facts pertaining to the flying and use of homing pigeons were considered:

1. When released at unfamiliar and distant points, they usually fly in large circles for a matter of minutes before moving off in a straight line. When training flights have been experienced once or twice daily for weeks, and pigeons are released individually from new locations around the compass, they often sense the correct direction, after having flown only one or a fraction of a complete circle.

2. Homing pigeons are unable to navigate in a thick haze or fog or in complete darkness. Blinded or hooded birds fly first in a large circle and then in a decreasing spiral, gradually decending until about six feet above ground level, after which a "crash" landing is made.

3. Pigeons are unable to navigate successfully in winds much over thirty-five miles per hour.

4. After reaching four or five weeks of age, homing pigeons can be trained "around the compass" for six or eight weeks at increasing distances of one, two, four, eight, sixteen, thirty-two miles (repeating each distance one or two times before increasing), after which they are easily capable of navigating flights of distances up to seventy miles and more. With a few more weeks of training, flights of one to two hundred miles, or even more, are readily accomplished. A year later, with some additional short training flights added to their experience, they can readily navigate home from four hundred miles, without previous experience of any kind in the new territory.

5. Written reports by the Army and Navy Communications $^{5}$ as well as numerous oral re-

\footnotetext{
* D. R. Griffin, "The Sensory Basis of Bird Navigation," Quarterly Review of Biology, 1 (1944).

† W. M. Levi, The Pigeon (R. L. Bryan Company, Columbia, South Carolina, 1944).

'Experiments With Homing Pigeons' Sensitivity to Radio Frequency Waves, conducted by 285 th Signal Pigeon Company, March 1945.
}

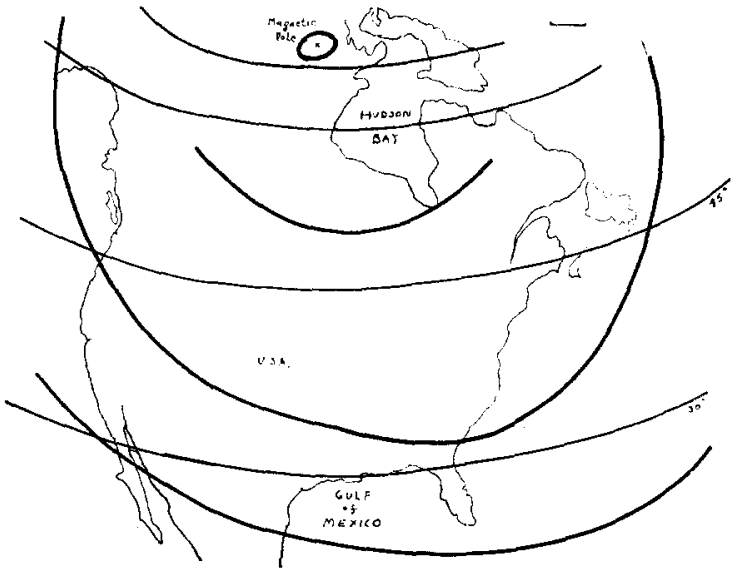

MAP I. North American section of earth-globe showing lines of equal magnetic vertical-Coriolis gridwork. South magnetic pole displacement from north terrestrial pole is roughly about $20^{\circ}$ or 1400 miles.

ports by representatives of fying clubs and individuals, indicate that pigeons are confused and are unable to orient themselves when released from points near powerful radio and radar broadcasting stations. There are some indications that the audiofrequencies rather than the carrier-frequencies are the disturbing factor.

The following theory is presented as the first complete working hypothesis to explain homingpigeon navigation.

Three major factors are involved:

1. Sensitivity of birds to the effect of flying through a magnetic field.

2. Sensitivity to the forces, produced by the earth's rotation, acting on masses moving over its surface in a straight line (part of the wellknown Coriolis effect which is a function of latitude).

3. Visual sensitivity to velocity over the earth's surface (land speed).

By correlating the results of the first and last of these sensitivities the bird can detect his "magnetic latitude." This differs from his true latitude because the magnetic poles are grossly and asymmetrically displaced from the earth's poles (Map I). By similar correlation of the second and last sensitivities it is possible to detect the true latitude.

The effective result of these two correlations is that the bird can recognize his home locality at the intersection of a characteristic line in the 


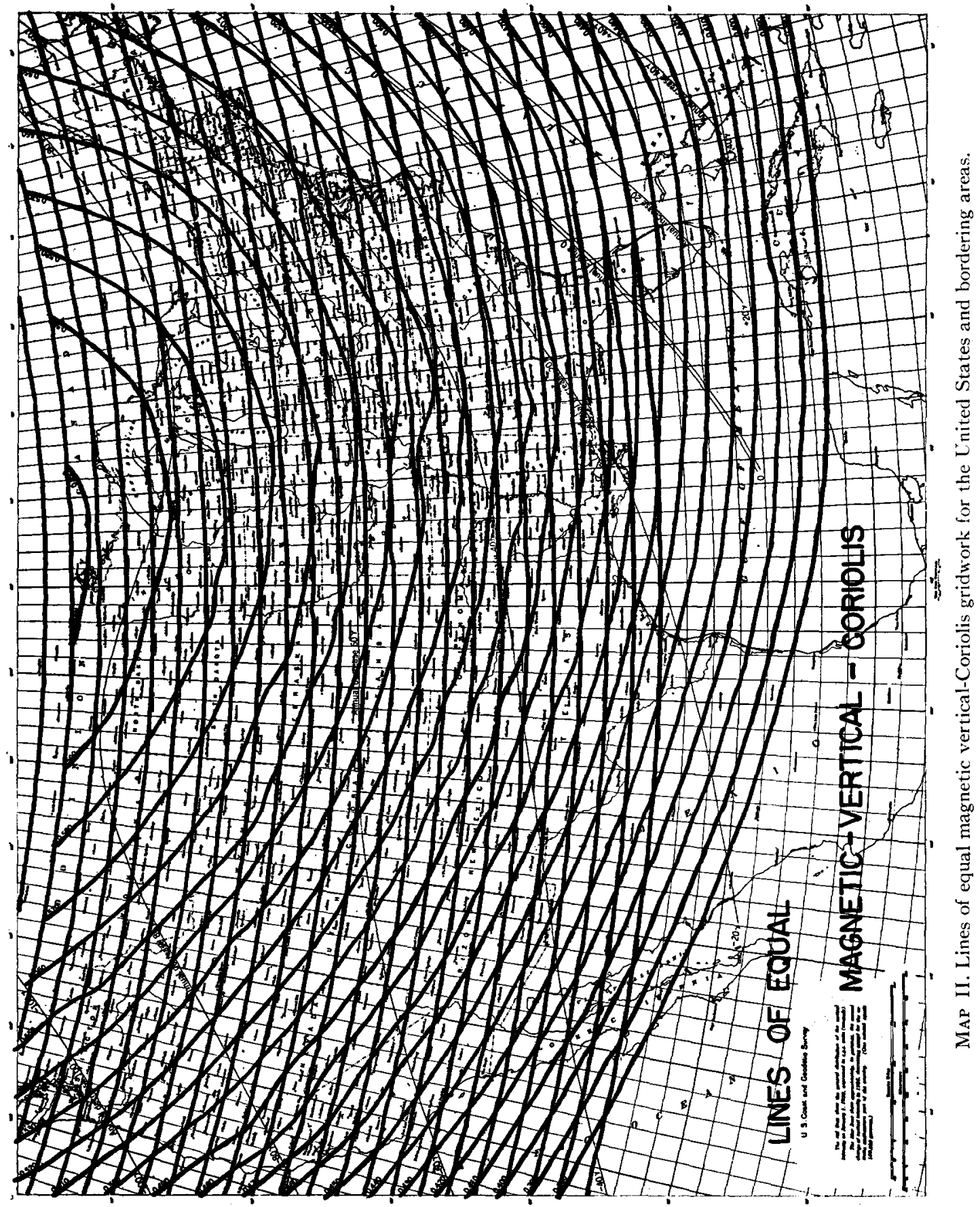


earth's magnetic vertical field with a characteristic line of latitude.

Thus it appears that the secret of bird navigation depends on the displacement of the magnetic poles from the rotational poles of the earth with the subsequent intersection of the lines of equal magnetic-vertical intensity with latitude lines (Maps I and II).

The fact is that it was a study of Map II in relation to the failure of homing pigeons near Indianapolis, Indiana, ${ }^{6}$ which gave the first clue to the present theory. As will be noted, in that area the two sets of curves are essentially parallel. Thus in that section, the two sets of correlations guide the birds to a line many miles long instead of to an approximate point. It should be added that the study of maps involving lines of equal magnetic declination, equal magnetic dip, equal magnetic horizontal intensity, equal total magnetic intensity, or any combination of these failed to show such parallelism in southern Indiana.

In operation, the navigation may be as follows:

1. A bird is sensitive by virtue of some organ or organs to the magnitude of the effect of its motion in flight through the vertical component of the earth's magnetic field. ${ }^{7}$ This effect which must be correlated with its land speed, is a direct function of the bird's horizontal velocity, and the distance from the magnetic poles. It is a maximum at the poles and decreases somewhat irregularly from each pole toward a line approximately half-way between. By this means, a bird, if flying in a location of magnetic vertical field intensity different from its home, can consciously fly in a direction which will bring its land-speed magnetic vertical-field effect ${ }^{8}$ back to that to which it is accustomed during its normal flight around home territory. Since the lines of equal vertical magnetic-field intensity are irregular closed curves centering around the magnetic poles, it is evident that they represent one set of lines involving a velocity-magnetic vertical-field-gradient pattern which is part of our proposed navigational grid system.

\footnotetext{
${ }^{6}$ F. J. Saterteig, "Indianapolis," Am. Racing Pigeon News, Nov. 1942, p. 1.

${ }^{7}$ See reports to the U. S. Army Signal Corps listed in the Foreword.

${ }^{8}$ This effect may be the same phenomenon as the socalled "electromagnetic effect," it will subsequently be referred to as such for the sake of brevity.
}

2. A bird is sensitive by virtue of some organ or organs to the magnitude of the Coriolis effect. This latter results from a natural relationship between the earth's rotational velocity and motion of a body over the earth. The forces involved are a direct function of the earth's rotational speed, the speed of a body moving over the earth's surface, and the latitude of the moving body. As in the case of the electromagnetic effect, the bird must correlate its land speed with the magnitude of this force in order to use it as a guide. The lines of equal Coriolis force are true circles coincident with parallels of latitude. Hence, if a bird, usually subject to the Coriolis effect of normal flying around home territory, is displaced north or south, he need only fly in a direction which will bring the "feel" of the Coriolis land-speed relation back to normal and he will be back on his own latitude circle. These circles represent a second set of lines which in bird orientation involves a force land-speedgradient pattern which is a part of our postulated navigational grid system.

Map I illustrates the existence on the earth of a gridwork of two distinct sets of curves, representing the land speed $v s$. electromagnetic effect and the land speed $v s$. Coriolis effect. For any horizontally moving body over the earth's surface these intersecting curves give rise to a system of unique pairs of conjugate points.

This conception offered an opportunity for the experimental testing of the theory. If a bird locates its home by navigating to the intersection of the proper magnetic vertical and the proper latitude, he should as readily navigate to the conjugate point as to his home, if released nearer the former. As can be seen on Map II the conjugate point of State College, Pennsylvania is in central Nebraska. A location near Kearney, Nebraska, has been used for checking the theory, as will be described below.

\section{EFFECT OF MOTION THROUGH THE MAGNETIC FIELD}

It is a well-known fact that whenever a continuous ring or circle of some material medium is rotated in a magnetic field, so that the lines of flux are cut, an e.m.f. is induced. This is said to result from a change of flux linkage and its magnitude is given by: 


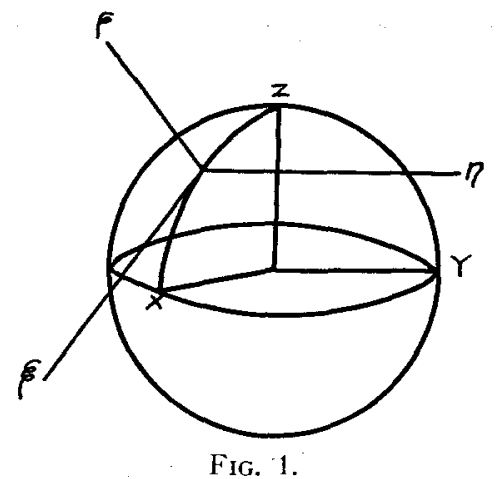

e.m.f. $=d \psi / 10^{8} d t \quad($ e.m.f. $=$ induced voltage $) ;$ $d \psi / d t=$ rate cutting of flux in number of lines cut per second ;

$10^{8}=$ factor needed to give result in volts or joules per coulomb.

Although it is quite customary in physics texts to give problems in which it is required to find the voltage induced when a straight wire of given length cuts a magnetic field of given strength and orientation at a given velocity, no known experiment has ever shown conclusively that an e.m.f. is induced under these latter conditions. Nevertheless, in dealing with bird navigational flight in this theory the assumption is made that the bird in some way senses the effect of flying normally through the vertical component of the earth's magnetic field, and the laws obeyed are the same or analogous to the electromagnetic effect. Whether or not it is the latter, as is ordinarily meant in the physical sense, or a phenomenon for which man has not yet conceived a picture, does not alter its general application to the theory involved. For if a bird navigates according to a pattern which fits exactly into the vertical, magnetic-field Coriolis gridwork, illustrated in Map II, some mechanism relating it to bird navigation exists, even though man does not yet comprehend its full import. A flying bird or any object moving at right angles to a magnetic field or its component would constitute a system comparable to a moving straight wire mentioned above rather than a rotating ring.

Should the sensitivity of the bird involve the ordinary laws of electromagnetism, the magnitude of the induced voltage for a bird flying forty miles per hour at State College, Pennsylvania, where the vertical component of magnetic field intensity is .556 oersted, ${ }^{9}$ would be :

$$
\begin{aligned}
\text { e.m.f. } & =\frac{d \psi}{10^{8} d t}=\frac{H \cdot L}{10^{8}} \frac{d s}{d t}=\frac{.556 \times 1 \times 1798}{10^{8}} \\
& =10^{-5} \text { or } 10 \text { microvolts per cm of length. }
\end{aligned}
$$

$d \psi=$ lines of flux cut, $H=$ field intensity, $L$ $=$ length of conductor, $40 \mathrm{mi} . / \mathrm{hr} .=59 \mathrm{ft}$. $/ \mathrm{sec}$. or $1798 \mathrm{~cm} / \mathrm{sec}$. This voltage might make itself felt either across the nerves in the wings and other gross parts of the bird or across the eye, the ear, or any organ or parts of organs.

Not only sensitivity to the absolute value but also reaction to its variation is necessary to guide the bird in the compensatory direction. For this reason the increments of magnetic vertical-field intensity should be examined.

Average values of the vertical component of magnetic-field intensity are 0.60 oersted at a distance of $15^{\circ}$ from the setth magnetic pole in the Hudson Bay region, and 0.68 oersted at a distance of approximately 5 to 8 degrees from the South Magnetic Pole in the general region south of New Zealand. These values diminish to zero at points along great circles, approximately midway between. In equatorial regions the variation of the vertical intensity in a general northsouth direction is about .01 oersted per degree. In the United States the corresponding variation is roughly .007 oersted per degree. Since all experimental work involved in this report has been done in this country the latter value will be considered for illustrative purposes.

$$
\begin{aligned}
& \frac{d(\text { e.m.f. })}{d \varphi}=\frac{L}{10^{8}} \frac{d s}{d t} \frac{d H}{d \varphi}=\frac{1.798 \times 10 \times 7 \times 10^{-3}}{10^{8}} \\
& =\frac{1 \times 1798 \times .007}{10^{8}}=\frac{1 \times 1.798 \times 7}{10^{8}}=12.6 \times 10^{-8}
\end{aligned}
$$

$=.13$ microvolt change for approximately each

degree or seventy miles of flight (a change of 1.3 percent per degree).

$d \varphi=$ increment of "magnetic latitude"

\footnotetext{
${ }^{9}$ World values of $H$ may be obtained from map No. 1702 , "The vertical intensity of the earth's magnetic force," published by the Hydrographic Office, Washington, D. C. Values for the United States of America from Booklet and Serial number 602, as previously indicated.
} 


\section{EFFECT OF MOTION THROUGH THE CORIOLIS FIELD}

The following equations represent the Coriolis acceleration or force per unit mass and were obtained from A. G. Webster's Dynamics (G. E. Stechert and Company, New York), p. 320-322.

$$
\begin{gathered}
d^{2} \xi / d t^{2}=2 \Omega \sin \varphi(d \eta / d t), \quad(\text { see Fig. 1) } \\
d^{2} \eta / d t^{2}=-2 \Omega\{(d \xi / d t) \sin \varphi+(d \zeta / d t) \cos \varphi\}, \\
d^{2} \zeta / d t^{2}=-g+2 \Omega \cos \varphi(d \eta / d t) .
\end{gathered}
$$

$\varphi=$ latitude of place, $\Omega=$ angular rotational speed of the earth, $-g=$ acceleration of gravity, $\pm \eta=$ distance moved east or west on the earth surface, $\pm \zeta=$ distance moved north or south on the earth surface, $\pm \xi=$ distance moved toward zenith or nadir, $t=$ time.

According to these equations, it is apparent that a bird might conceivably make use of Coriolis forces due to its motion in any direction (i.e., horizontal, vertical, or their resultant directions) as part of its system of navigation. Only horizontal motions are considered as part of this theory but if vertical motions were also included, no basic changes would be involved in the discussion, since in any case the magnitude of the resulting Coriolis forces will still be a function only of $\Omega, \sin \varphi$ and $d s / d t$. Since the bird's continuous and normal motion in homing is horizontal, only the latter will be considered. Hence the following modified equation is obtained by combining (1) and (2):

$$
\begin{aligned}
& a=\left[\left(d^{2} \xi / d t^{2}\right)^{2}+\left(d^{2} \eta / d t^{2}\right)^{2}\right]^{\frac{1}{2}} \\
& =2 \Omega \sin \varphi\left[(d \eta / d t)^{2}+(d \xi / d t)^{2}\right]^{\frac{1}{2}} . \\
& =2 \Omega \sin \varphi(d s / d t)
\end{aligned}
$$

In (2) the term $(d \zeta / d t) \cos \varphi$ is zero since motion in the $\zeta$ (vertical) direction is considered zero. Equation (3) denotes that there will be a vertical force of Coriolis resulting whenever there is a component of horizontal velocity eastward or westward. When the motion is in the $+\eta$ (eastward) direction it is downward, and vice versa. The value of $d^{2} \zeta / d t^{2}$ (insofar as the bird is concerned) varies above or below $-g$ when it flies in any horizontal direction having a component of velocity either east or west. This vertical force could also be part of the bird's orienting mechanism and might operate to help maintain migrat- ing birds on a true north or south course. In the bird's home territory where it recognizes local landmarks and awareness of direction is a factor, as in piloting operations, this vertical force may again operate in guiding him. As previously stated, even though this vertical force, or the term $(d \zeta / d t) \cos \varphi$ (in Eq. (2)), actually enters the picture, it in no way changes the over-all concept of the Coriolis land-speed relation to bird navigation as set forth in the theory. As homing pigeons are known to fly at rates of twenty to sixty miles per hour, a value of forty miles per hour, or fifty-nine feet per second, will again be used for making an illustrative calculation. A median value of $45^{\circ}$ latitude will also be chosen arbitrarily to go with this arbitrary speed value. Substituting in Eq. (4) :

$$
\begin{aligned}
a= & 2 \times \frac{2 \pi}{86,400} \times .707 \times 59 \\
& =\frac{4 \times 3.14 \times 7.07 \times 5.9}{8.64 \times 10^{4}}=\frac{524}{8.64 \times 10^{4}}=61 \times 10^{-4} \\
& =.0061 \text { feet per second per second. }
\end{aligned}
$$

The direction of this Coriolis acceleration on the northern hemisphere is to the right and on the southern hemisphere to the left of the line of flight. This latter is commonly known to produce the counter-clockwise and clockwise whirlpools of moving fluids on the northern and southern hemispheres of the earth.

As a result of this accleration, the force per unit mass would be $F=\mathrm{ma}=1 \times .0061$ or .0061 poundal per pound at $45^{\circ}$ latitude, and a speed of forty miles per hour. Or in terms of rate change of Coriolis effect with respect to time:

$$
\begin{gathered}
\text { But } \\
\frac{d \phi}{d t}=\frac{1 d s}{r} \cdot \frac{d t}{d t} \\
\therefore \frac{d a}{d t}=\frac{2 \Omega \cos \varphi(d s / d t)^{2}}{r}=\frac{2 \times 2 \pi \times .707 \times 59 \times 59}{86400 \times 3955 \times 5280} \\
=\frac{4 \times 3.14 \times 7.07 \times 5.9 \times 5.9 \times 10^{1}}{8.64 \times 3.96 \times 5.28 \times 10^{10}} \\
=1.72 \times 10^{-8} \mathrm{ft} . / \mathrm{sec} . / \mathrm{sec} . \text { each second }
\end{gathered}
$$$$
\frac{d a}{d t}=2 \Omega-\cos \varphi \frac{d \phi}{d t} d t
$$ 
or about

$$
10.8 \times 10^{-5}=.000108 \frac{\mathrm{ft} . / \mathrm{sec} . / \mathrm{sec}}{\text { degree }}
$$

This 1.7 percent change of force per unit mass therefore occurs in flying one degree normal to the parallel circles of equal Coriolis effect at $45^{\circ}$ latitude. The absolute value of Coriolis acceleration varies from maximum $1.00 / .707 \times .0060$ $=.0085 \mathrm{ft}$. $/ \mathrm{sec}$. $/ \mathrm{sec}$. at forty $\mathrm{mi}$. $/ \mathrm{hr}$. at the poles to zero at the equator.

Judging by these tiny increments of Coriolis force and magnetic effect which the bird would have to correlate with land speed for navigational guidance, the tendency is to reject its validity.

Also it is certain that there is a physical basis for this ability to navigate which pigeons constantly demonstrate. It seems fair to assert that if the directives involved were of a gross magnitude, with modern scientific tools and mathematical means of investigation they would have been uncovered before now.

Examination of Maps I and II reveals that in the equal magnetic-vertical intensity Coriolisforce gridwork each pair of intersecting lines cross each other at least twice. In addition, about midway between the pairs of conjugate intersections, approximate parallelism often exists over a considerable portion of their lengths. These conditions also differ from a perfect pattern because large segregated surface deposits of magnetic materials on the earth prevent the equal magnetic-vertical lines from more than simulating the form of a true circle. On the United States Map II it can be seen that this condition of parallelism obtains over a fairly wide band of land area, including parts of Wisconsin, Illinois, Indiana, Kentucky, Tennessee, etc.

The above-mentioned relationships suggest that birds trained to navigate to one point of intersection of two lines toward the east, should,

TABLE I.

\begin{tabular}{cccccc}
\hline Nov. & Day & $\begin{array}{c}\text { Two copper } \\
\text { plates }\end{array}$ & $\begin{array}{c}\text { Two } \\
\text { magnets }\end{array}$ & $\begin{array}{c}\text { Lost one } \\
\text { magnet }\end{array}$ & $\begin{array}{c}\text { Lost two } \\
\text { magnets }\end{array}$ \\
\hline 7 & 1st & 5 & - & 1 & - \\
8 & 2nd & 3 & - & - & - \\
9 & 3rd & - & - & - & - \\
10 & 4 th & - & 1 & 2 & 2 \\
\hline
\end{tabular}

if released nearer to their conjugate point, fly preferentially toward the latter. Likewise, the region of parallelism or tangency should be one of confusion for navigating birds. If trained within this region their home would not contain a unique point with reference to the theory, or, if trained outside but released within this region, they would be in the dilemma of being apparently able to fly toward their home in either of two directions, approximately $180^{\circ}$ apart. This suggests the experiments of training homing pigeons to navigate to one location and releasing them near the conjugate point of the location, or at points in between the two conjugates to see if they react to the home or conjugate positions.

Another suggested experiment arises from the idea that if birds are guided by the effect of flight through the vertical component of the earth's magnetic field, they should become confused if a sufficiently strong superimposed magnetic field moves upward and downward across their bodies simultaneously. These and the previously mentioned considerations led to the following set of experiments which will be described in chronological order.

\section{EXPERIMENT I}

\section{The Magnetic Wing Experiment, November 7, 1943}

The first experimental test of the theory was. made by superimposing on homing pigeons while in navigational flight, a magnetic field moved up and down by their wing motion. This was accomplished by attaching hyflux-chrome magnets on the under side of the wings, between the first and second joints.

The normal magnetic effect would be the one due to the somewhat pulsating forward motion at right angles through the vertical component of the earth's magnetic field. If a number of homing pigeons with the superimposed moving experimental field were unable to home normally and a like number with identical training but with attached copper plates of the same approximate mass and size should home from the same release point in the normal fashion, it would be an indication that the earth's magnetic field plays a part in bird navigational guidance. 
The birds used in this experiment were raised and trained for it by Mr. Lowell Gable of Paoli, Pennsylvania. Because he is an educated man with a scientific mind and one of the foremost in the field of homing pigeon racing, it was felt the experiment would be more significant than under other circumstances. Mr. Gable carefully trained twenty of his best young birds to pilot and navigate to his loft from distances up to one-hundred miles. The training flights were always from stations to the west, northwest, and north of Paoli so that the birds would not become familiar with land areas to the south and southwest over which the final experimental flights would be run. They were singly released many times at fifty to one-hundred airline miles or more to insure individual navigating skill and eliminate those that simply followed their loft-mates home. Between 10:05 A.M. and 12:04 P.M. on the morning of November 7, 1943, the twenty trained birds were released at a point eight miles southeast of Bellaire, Maryland. The airline distance to the loft at Paoli was about sixty-five miles. To the wings of each bird in turn was attached either a pair of magnetic or copper plates before it was set free. None was released until the previous one had been out of sight for five minutes. Its general direction of travel at time of disappearance was carefully noted. All even-numbered birds carried hyflux-chrome magnets, whereas the odd-numbered ones had copper plates attached to their wings. Both magnets and copper plates used were $1^{\prime \prime} \times .218^{\prime \prime} \times .025^{\prime \prime}$ and weighed approximately $.8 \mathrm{gram}$. Attachments were made on the under side of the manus portions of the wings. Since any attachment involving the wing feathers or feather follicles would have caused rapid and serious irritations, a plan had been devised by which thin silk strands were threaded through the flesh between the third and fourth metacarpal bones. Previous and later tests showed that no soreness or injury resulted from long attachment or from hundreds of miles of flying with the plates remaining in position.

The record of their returns as supplied by Mr. Lowell Gable is shown in Table I.

The magnets on the wings of the birds were separated about $12^{\prime \prime}$ between centers when in a horizontal, full-spread position. They were of such strength as to produce a horizontal in-
TABLE II.

\footnotetext{
3 with copper plates deviated less than $10^{\circ}$ from a direct line toward the home loft, sixty-five airline miles to the northeast.

4 with copper were less than $50^{\circ}$ off from this line toward the north.

3 others with copper were less than $30^{\circ}$ off from this line toward the east.

4 with magnets were about $45^{\circ}$ off from this line.

2 with magnets were more than $90^{\circ}$ from this line.

3 with magnets were approximately $130^{\circ}$ off from this line.

1 with magnets flew in the exactly opposite direction from the home loft.
}

tensity, half-way between them, about equal to that of the earth's magnetic horizontal component in the region of State College. This value is approximately .172 oersted.

By assuming that the magnets move up and down with approximately simple harmonic motion and estimating the wing beats at 180 per second and their amplitude at $\frac{1}{8}$ foot, a value of .12 microvolt per centimeter was computed for the maximum induced e.m.f. per centimeter on the bird's anatomy.

This value of .12 microvolt per centimeter, as can be seen, is of the same order of magnitude as the change of e.m.f. involved in flying eighty miles toward or away from the normal magneticvertical line previously considered at $45^{\circ}$ latitude. Both its magnitude and its pulsating character, i.e., changing three-hundred and sixty times per minute, from zero to .12 microvolt per centimeter and back to zero, might conceivably serve to confuse the bird and upset his navigating prowess during its occurrence.

The following important points should be noted :

1. Eight of ten birds with copper plates returned home during the first two days.

2. Of those returning, having originally had two magnets each and subsequently losing either one or both, only one with one magnet got home before the fourth day.

3. Only one bird with two magnets got home at all and it arrived on the fourth day.

4. None of the other birds, at this writing, has ever returned.

The final results of the experiment were well presaged by the directions in which the birds left the release point. Each was carefully watched out of sight before another was released. Table II 
TABLE III. Showing release points and final locations of birds released.

\begin{tabular}{|c|c|c|c|c|c|}
\hline Release & No. & Band & Place found & Date & $\begin{array}{l}\text { Wind velocity, dir. to } \\
\text { lofts, temp., storms, etc. }\end{array}$ \\
\hline $\begin{array}{l}\text { Release No. } 1 \\
\text { St. Paul, Neb., } \\
\text { June } 29,1944, \\
\text { distance } 43 \text { miles, } \\
14 \text { birds, } \\
7 \text { reported }\end{array}$ & $\begin{array}{l}1 \\
2 \\
3 \\
4 \\
5 \\
6 \\
7\end{array}$ & $\begin{array}{l}\text { AU43 PA11891 } \\
\text { WSC41 D2020 } \\
\text { IF431 5014 } \\
\text { AU43 U5115 } \\
\text { IF43 K4994 } \\
\text { AU43 V50825 } \\
\text { IF43 K5013 }\end{array}$ & $\begin{array}{l}\text { St. Paul } \\
\text { Grand Island } \\
\text { Grand Island } \\
\text { Ulysses } \\
\text { Callaway } \\
\text { Franklin } \\
\text { Belgrade }\end{array}$ & $\begin{array}{l}6 / 30 \\
7 / 1 \\
7 / 1 \\
7 / 1 \\
7 / 3 \\
7 / 4 \\
7 / 5\end{array}$ & $\begin{array}{l}20 \mathrm{mi} . / \text { hr. E.N.E. S.W. } \\
71^{\circ} \mathrm{F} \\
18 \text { thunderstorms during day }\end{array}$ \\
\hline $\begin{array}{l}\text { Release No. } 2 \\
\text { Hastings, Neb. } \\
\text { June } 30,1944, \\
\text { distance } 42 \text { miles } \\
13 \text { birds, } \\
\quad 5 \text { reported }\end{array}$ & $\begin{array}{l}1 \\
2 \\
3 \\
4 \\
5\end{array}$ & $\begin{array}{l}\text { AU44 P48107 } \\
\text { WB 31 } \\
\text { AU44 P8113 } \\
\text { AU43 V50824 } \\
\text { AU43 PA11886 }\end{array}$ & $\begin{array}{l}\text { Clay Center } \\
\text { Greeley } \\
\text { Harrard } \\
\text { Heartwell } \\
\text { Hastings }\end{array}$ & $\begin{array}{l}7 / 2 \\
7 / 3 \\
7 / 3 \\
7 / 2 \\
9 / 11\end{array}$ & $\begin{array}{l}22 \mathrm{mi} . / \mathrm{hr} . \text { S.E. N.W. } \\
80^{\circ} \mathrm{F} \\
16 \text { thunderstorms }\end{array}$ \\
\hline $\begin{array}{l}\text { Release No. } 3 \\
\text { Broken Bow, Neb., } \\
\text { July } 1,1944 \\
\text { distance } 50 \mathrm{mi} . \\
20 \text { birds, } \\
\quad 10 \text { reported }\end{array}$ & $\begin{array}{r}1 \\
2 \\
3 \\
4 \\
5 \\
6 \\
7 \\
8 \\
9 \\
10\end{array}$ & $\begin{array}{l}\text { AU44 V35151 } \\
\text { AU44 V35165 } \\
\text { AU44 P48110 } \\
\text { AU44 P48320 } \\
\text { AU44 V35137 } \\
\text { AU44 V35160 } \\
\text { AU43 V58822 } \\
\text { IF43 BER414 } \\
\text { AU43 U5389 } \\
\text { AU43 V5111 }\end{array}$ & $\begin{array}{l}\text { Sargent } \\
\text { Ericson } \\
\text { Bassett } \\
\text { Mason City } \\
\text { Ansley } \\
\text { Ansley } \\
\text { Comstock } \\
\text { Broken Bow } \\
\text { Taylor } \\
12 \text { W Loup City }\end{array}$ & $\begin{array}{l}7 / 3 \\
7 / 3 \\
7 / 3 \\
7 / 2 \\
7 / 8 \\
7 / 8 \\
7 / 2 \\
7 / 6 \\
7 / 3\end{array}$ & $\begin{array}{l}20 \mathrm{mi} . / \text { hr. S. S.E. } \\
\text { temperature? } \\
3 \text { thunderstorms }\end{array}$ \\
\hline $\begin{array}{l}\text { Release No. } 4 \\
\text { Minden, Neb., } \\
\text { July } 2,1944 \\
\text { distance } 25 \mathrm{mi} ., \\
15 \text { birds, } \\
\quad 7 \text { reported }\end{array}$ & $\begin{array}{l}1 \\
2 \\
3 \\
4 \\
5 \\
6 \\
7\end{array}$ & $\begin{array}{ll}\text { WB26 } \\
\text { AU44 } & \text { V35162 } \\
\text { AU44 } & \text { P48117 } \\
\text { *AU43 } & \text { Y4794 } \\
\text { AU43 } & \text { X } 27252 \\
\text { AU43 } & \text { PA11780 } \\
\text { AU43 } & \text { M4820 }\end{array}$ & $\begin{array}{l}\text { Heartwell } \\
\text { Kenesaw } \\
\text { Longpine } \\
5 \text { mi. E. of Kearney } \\
\text { Kenesaw } \\
\text { Holredge } \\
\text { Lexington }\end{array}$ & $\begin{array}{l}7 / 4 \\
7 / 5 \\
7 / 7 \\
7 / 5 \\
7 / 5 \\
7 / 6 \\
7 / 7\end{array}$ & $\begin{array}{l}24 \mathrm{mi} . / \text { hr. S.S.W. N.N.W. } \\
93^{\circ} \mathrm{F} \\
7 \text { thunderstorms } \\
\text { *AU43 Y4794-a Heitzman bird } \\
\text { came within } 3 \text { miles of finding } \\
\text { loft }\end{array}$ \\
\hline $\begin{array}{l}\text { Release No. } 5 \text {, } \\
\text { Havens, Neb., } \\
\text { July } 3,1944 \\
\text { distance } 70 \mathrm{mi} \text {, } \\
17 \text { birds, } \\
\quad 4 \text { reported }\end{array}$ & $\begin{array}{l}1 \\
2 \\
3 \\
4\end{array}$ & $\begin{array}{ll}\text { *WB } 28 \\
\text { AU44 } 26649 \\
\text { AU44 } & \text { V35141 } \\
\text { AU43 } & \text { PA11696 }\end{array}$ & $\begin{array}{l}\text { East Loft } \\
\text { Minden } \\
\text { Lexington } \\
\text { Ashton }\end{array}$ & $\begin{array}{c}7 / 5 \\
7 / 4 \\
7 / 4 \\
11 / 23\end{array}$ & $\begin{array}{l}21 \mathrm{mi} . / \mathrm{hr} . \mathrm{S} . \mathrm{E} . \\
91^{\circ} \mathrm{F} \\
23 \text { storms } \\
\text { *A Heissler (York, Pa.) bird flew } 70 \\
\text { mi. and found loft. Direction was } \\
\text { away from State College }\end{array}$ \\
\hline $\begin{array}{l}\text { Release No. } 6 \\
\text { Cozad, Neb., } \\
\text { July } 4,1944, \\
\text { distance } 48 \mathrm{mi} \text {, } \\
16 \text { birds, } \\
\quad 9 \text { reported }\end{array}$ & $\begin{array}{l}1 \\
2 \\
3 \\
4 \\
5 \\
6 \\
7 \\
8 \\
9\end{array}$ & $\begin{array}{l}\text { AU44 } 14356 \\
\text { AU44 H48122 } \\
\text { AU44 B335150 } \\
\text { AU44 V35159 } \\
\text { AU44 P48118 } \\
\text { WB 27 } \\
\text { AU43 DC1486 } \\
\text { IF43 B518 } \\
\text { AU43 J6506 }\end{array}$ & $\begin{array}{l}\text { Gothenburg } \\
\text { Burwell } \\
\text { Cozad } \\
\text { Cozad } \\
5 \mathrm{mi} \text {. N. Cozad } \\
\text { Oconto } \\
\text { Dunning } \\
\text { Bertrand } \\
11 \text { mi. NW Miller }\end{array}$ & $\begin{array}{l}7 / 5 \\
7 / 6 \\
7 / 6 \\
7 / 6 \\
9 / 1 \\
9 / 15 \\
7 / 6 \\
7 / 26 \\
9 / 5\end{array}$ & $\begin{array}{l}17 \mathrm{mi} . / \mathrm{hr} . \mathrm{S} . \mathrm{E} . \\
81^{\circ} \mathrm{F} \\
11 \text { storms }\end{array}$ \\
\hline
\end{tabular}

indicates the general direction at which the birds went out of sight from the release point.

Since these birds were well trained and outstanding homing pigeons, Mr. Gable and others expert in the field of flying and racing homing pigeons expected at least two or possibly three of those with two magnets to home, just on the basis of their intelligence and ability to "hunt" their way home. On the basis of probability and chance a similar prediction would obtain.

\section{EXPERIMENT II}

\section{The First Nebraska Experiment}

With the positive though limited data for the electromagnetic phase of the theory secured, the groundwork was laid for testing the theory as a whole. Examination of the U. S. Coast and Geodetic Survey Map I revealed that the conjugate point of State College, Pennsylvania, (corrected for 1944) i.e., another position having. 
TABLE III.-Continued.

\begin{tabular}{|c|c|c|c|c|c|}
\hline Release & No. & Band & Place found & Date & $\begin{array}{l}\text { Wind velacity, dir. to } \\
\text { lofts, temp., storms, etc. }\end{array}$ \\
\hline $\begin{array}{l}\text { Release No. } 7 \\
\text { Columbus, Neb., } \\
\text { July } 7,1944, \\
\text { distance } 100 \text { miles, } \\
2 \text { birds released, } \\
\quad 1 \text { reported }\end{array}$ & 1 & AU44 P48109 & Thedford & $7 / 10$ & $21 \mathrm{mi} . / \mathrm{hr} .94^{\circ} 25$ storms \\
\hline $\begin{array}{l}\text { Release No. } 8 \\
20 \text { mi. east } \\
\text { Council Bluffs, Iowa; } \\
\text { July } 8,1944, \\
\text { distance } 185 \text { mi., } \\
1 \text { bird released, } \\
1 \text { received in west loft }\end{array}$ & 1 & IF43 B1014 & West lof $\mathrm{t}$ & $7 / 10$ & $\begin{array}{l}21 \mathrm{mi} / \mathrm{hr} \text {. N.E. } 77^{\circ} \mathrm{F} 18 \text { storms- } \\
\text { this bird flew } 185 \text { miles in a direc- } \\
\text { tion opposite from State College } \\
\text { and found the west loft near } \\
\text { Kearney }\end{array}$ \\
\hline $\begin{array}{l}\text { Special Release No. } 1 \\
\text { Lincoln, Neb., } \\
\text { May } 14,1944, \\
\text { distance } 120 \text { mi., } \\
12 \text { birds, } \\
\quad 5 \text { reported }\end{array}$ & $\begin{array}{l}1 \\
2 \\
3 \\
4 \\
5\end{array}$ & $\begin{array}{l}\text { RBC5951JF } \\
\text { NPAB } 3542 \\
A U-A 13726 \\
V E 14576 \\
A U-Y-6005\end{array}$ & $\begin{array}{l}15 \mathrm{mi} . \text { W. Grand Island } \\
\text { Lenora, Kan. } \\
\text { Fort Morgan, Col. } \\
\text { Odell, Neb. } \\
\text { Freemont, Neb. }\end{array}$ & $\begin{array}{l}5 / 16 \\
8 / 15 \\
5 / 24 \\
5 / 22 \\
5 / 16\end{array}$ & $\begin{array}{l}\text { Day of release was clear, no } \\
\text { winds, cool } \\
\text { (Birds trained up to } 50 \text { and more } \\
\text { miles) }\end{array}$ \\
\hline $\begin{array}{l}\text { Special Release No. } 2 \\
\text { Lincoln, Neb., } \\
\text { June } 25,1944, \\
12 \text { birds released, } \\
6 \text { reported }\end{array}$ & $\begin{array}{l}1 \\
2 \\
3 \\
4 \\
5 \\
6\end{array}$ & $\begin{array}{l}\text { E11712-43 } \\
42 W 18225 \\
\text { NPA43 B13239 } \\
\text { NPA44 B8117 } \\
41217857 \\
\text { NPA43-B13241 }\end{array}$ & $\begin{array}{l}\text { Lincoln, Neb. } \\
\text { Lincoln, Neb. } \\
\text { Lincoln, Neb. } \\
\text { Lincoln, Neb. } \\
\text { Wahoo, Neb. later L.ind- } \\
\text { wood, Neb. } \\
\text { Hebron, Neb. }\end{array}$ & $\begin{array}{l}7 / 25 \\
7 / 17 \\
7 / 25 \\
6 / 24 \\
6 / 26 \\
7 / 6 \\
6 / 30\end{array}$ & $\begin{array}{l}\text { Weather clear } \\
\text { Slight south wind }\end{array}$ \\
\hline $\begin{array}{l}\text { Special Release No. } 3 \\
\text { Berkeley Springs, Va., } \\
\text { Cozad, Neb. birds } \\
\text { September } 16,1944 \\
\text { distance } 100 \text { miles } \\
\text { J. A. Rendle birds, } \\
12 \text { birds released, } \\
6 \text { reported }\end{array}$ & $\begin{array}{l}1 \\
2 \\
3 \\
4 \\
5 \\
6\end{array}$ & $\begin{array}{l}\text { AU44 } W 8831 \\
\text { AU44 W8849 } \\
\text { AU44 W8852 } \\
\text { AU44 W8841 } \\
\text { AU43 A1436 } \\
\text { AU44 W3851 }\end{array}$ & $\begin{array}{l}\text { Pittsburgh, Pa. } \\
\text { Palmerton, Pa. } \\
\text { Freeland, Pa. } \\
\text { Near Berkeley Springs, Va. } \\
\text { E. Liverpool, Ohio } \\
\text { Portage, Pa. }\end{array}$ & $\begin{array}{c}9 / 20 \\
10 / 2 \\
9 / 25 \\
9 / 19 \\
9 / 20 \\
9 / 26\end{array}$ & $\begin{array}{l}\text { Weather was clear } \\
\text { Very light breeze } \\
\text { Haze in distance } \\
\text { Birds released in sets of } 3 \text { 's }\end{array}$ \\
\hline
\end{tabular}

identical values of magnetic vertical intensity and Coriolis force, lies in about the south-central portion of Nebraska (ten miles north of Kearney). A plan was worked out whereby a group of one hundred or more carefully selected homing pigeons would be settled ${ }^{10}$ and trained at State College, after which the birds and lofts would be transferred to the above conjugate point. Tests would then be made to determine if they would fly from the surrounding regions toward that point instead of heading for State College, Pennsylvania.

With this plan in view, training flights up to fifty miles around State College were decided upon and the birds were housed in a conspicu-

\footnotetext{
${ }^{10}$ Having been in full flight around loft, the bird returns and enters it. During his first free flight outdoors even though raised on the spot, it is easily frightened off in a panic, and may fail to take visual account of its surroundings. On a second release it is practically certain to return.
}

ously designed and painted loft so it could be seen from as great a distance as possible. In addition, it was moved ${ }^{11}$ each day so that the occupants, returning from training flights, would become accustomed to looking for the loft and not for familiar landmarks nearby. A five-foot observation balloon was raised each day about one-hundred and fifty feet above the loft as an additional beacon or guide. All these plans were executed carefully. The loft had a peak resembling a church spire and the whole was painted a brilliant yellow. It was moved two hundred feet each day and during the training period traveled a distance, by tractor power, of about three miles in a zigzag path over and across the college farms. The birds were given initial

${ }^{11}$ Its location was shifted 200 feet each day for training flights of the birds, and never returned to a previous location. 
piloting training flights ${ }^{12}$ of one, two, four, eight, and sixteen miles in several directions around the compass. From then on for a period of three months they had practice flights twice daily up to fifty and more miles. There was seldom a half-day during which they were not released at some new point around the compass. Care was used to prevent repetitional flights which might either aid or hinder them in the Nebraska experiment. It is known that repeated training during the same part of the day and over the same terrain causes homing pigeons to fly habitually by the sun's direction. Near the end of the training period they were released from time to time in singles, doubles, and sets of five at twenty-five-mile airline distances.

On the day set for the start of the trip to Nebraska the birds were transported to Altoona by truck in one of the homing lofts. The shipment from there on was by express so the loft had been carefully designed to make it as large as possible and yet have it go inside the express car. During the entire 1100-mile trip the nests with eggs and young were cared for by the parent birds. On arrival in Kearney the loft was set on the fair grounds until magnetic measurements were made to check the values obtained from the U. S. Department of Commerce. Also a second loft had been built and previously shipped, to double the chance of the birds' finding one in case they navigated from the release points to the predicted conjugate point. Askania magnetometer measurements showed that the magnetic vertical-field intensity ten miles north of Kearney was the same as State College. Unfortunately, however, the field intensity gradually increased to about three times its normal value fifteen miles east and returned to its normal value ten miles beyond the anomaly. This condition meant that there were actually two conjugate points twenty-five miles apart, which called for a choice of placing the two lofts about 10 miles apart on either side of the point as planned according to the U. S. averages, or putting one at the normal conjugate point and the other twenty-five miles to the east at the anomalous conjugate point. The limited personnel and transportation facilities made the

\footnotetext{
${ }^{12}$ Short distance flights in which guidance could always be had by means of familiar landmarks.
}

twenty-five mile separation impractical. In addition, magnetic anomalies exert most of their influence fairly near the ground surface and for all these reasons the former strategy was used. The lofts were carefully placed five miles east and west of the calculated position on as high ground as could be found in that flat country. The birds were allowed to rest one day to acclimate themselves to the immediate surroundings.

Beginning with June 28, groups of birds were taken out to release points around the compass forty and more airline miles away. Each bird carried an army-message capsule with the words.

Important
Telegraph Immediately (collect)
Wildlife Research Unit
cooperating with
The Army Pigeon Service
c/o Fort Kearney Hotel
Kearney, Nebraska
Give band number
Place found
Date

The data obtained from these experiments are set forth in Table III. Releases No. 1 through No. 8 show the direct result of the experiment proper carried out between June 29 and July 8 . Releases labeled Specials No. 1 and No. 2 were performed before, and Special No. 3 after the main experiment and will be discussed later in the report. Map III, showing the state of Nebraska, contains a representation of the data shown on Table III except for that designated Special release No. 2 and No. 3. Each vector on the map represents graphically the sum total of the results for a given day or release number, the latter being in one-to-one correspondence on the map and table.

The flights of all birds reported were plotted as vectors on a preliminary work map and their vector sum obtained. The length of the latter was divided by the number of flights involved and the resultant vector represents the average result of all the recorded flights of that day. In referring to these in this report the term "total flight vector" will be used. A brief inspection of the total flight vectors for the eight days shows that numbers one, two, four, five, and eight not only point in the right direction but actually 


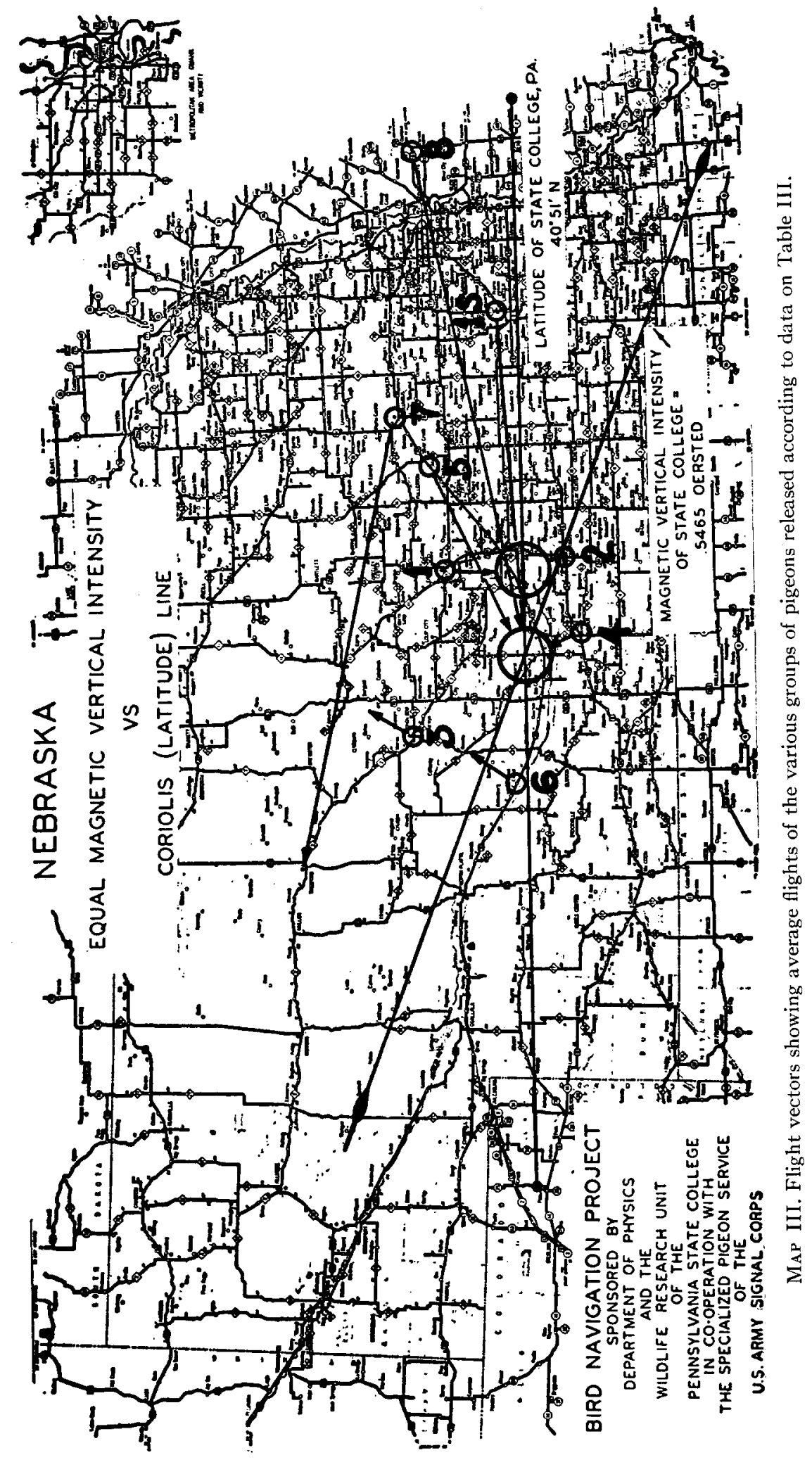


terminate within ten miles of one or the other of the two predicted points (the normal and anomalous ones). In fact, four, five, and eight, and Special No. 1 terminate with good precision. It is a notable fact that one bird, a blue bar female, WB28, of flight number five, flew the seventy miles, and found and entered the loft, despite hot, twenty-seven-mile per hour winds at right angles to its line of flight. Another unusually significant flight was that of the light blue check female, band number IF43B1014, the only bird flown that day, and the only one released outside of Nebraska. Its flight started at 3:30 P.M. about twenty miles east of Council Bluffs, Iowa. Not only did it fly the one hundred eighty-five airline miles across hot winds averaging twenty miles per hour but, as with the seventy-mile flight described above, it flew in the opposite direction from its home in State College to find and enter its $4 \times 4 \times 5$ foot loft displaced one thousand miles west of its home to the middle of a Nebraska grain field.

Total flight No. 6, representing nine reported birds, shows one of two anomalous results; these birds flew in an average direction $60^{\circ}$ off the theoretical course. One possible explanation is that there was a violent thunder storm between the release and loft positions that come up swiftly just after the last bird had been released. An important fact about this flight (true for all releases), is that the birds did not fly toward State College nor in random directions. None of the nine flew in a direction as much as $90^{\circ}$ off from the direction of the total flight vector. It is interesting to observe that, although the trend of this flight was not toward the home Coriolis line, it did follow almost the shortest route to the correct magnetic-vertical line of State College. Flight No. 3, also anomalous, has not the mitigating factor of an intervening electric storm, but it should be noted that the magnetic fields in the region involved are of the most distorted on record, according to Mr. James Affleck of The Gulf Research and Development Company. Release No. 7 is relatively unimportant since only one bird was reported of the two released. Actually, the flight direction is quite good, being only about $40^{\circ}$ off theoretical, and the bird may have flown in and out of the twenty-five-mile error distance for homing pigeons. Further, the hot Nebraska wind that day varied from twentysix to forty-eight miles per hour along the flight path, and the temperature averaged $94^{\circ} \mathrm{F}$ throughout.

Special release No. 1 represents an "advance guard" experiment in which twelve carefully trained homing pigeons were shipped to Lincoln, Nebraska, to be released by Professor P. A. Downs of the University of Nebraska. These birds, although not trained specifically for the experiment, had had several years of navigational and racing experience from points up to one hundred miles from State College, Pennsylvania. After they had been singly released and carefully watched out of sight, Dr. Downs later remarked that although they looked like good homers, unfortunately they went the wrong direction. Eight of the twelve had flown out of sight toward the west, exactly opposite from State College. Examination of the total flight vector for this group reveals that, for the five reported birds, making an average flight of onehundred thirty miles, it ends practically on the predicted position.

On June 25, Dr. Downs again released twelve homing pigeons of excellent flying stock raised in State College, Pennsylvania, this time "prisoners" up to a year or more in age, and without flying experience except inside their home loft and fly-pen. In observing their behavior at the liberation, it was noted that they merely scattered in random directions. Of six subsequently reported by telegraph, four remained at Lincoln, two others went in directions neither toward State College nor its Nebraska conjugate. This serves to illustrate the fact that even good homing pigeons must have flying experience and training, in order to respond to the navigating influences.

Special release No. 3 was the outcome of a visit to Mr. J. A. Rendle of Cozad, Nebraska, an outstanding racing pigeon expert, whose name had been given us by Major Otto Meyer of the U. S. Army Signal Corps. Informed of our experiment, he straightway offered to train some of his best young birds for a reverse test of the theory. The conjugate point of Cozad is somewhat east of the middle of Pennsylvania, but the magnetic deposits in the mountains scatter it into several positions east and west along the 
Coriolis line which is essentially the same (.04 of a degree north) as that of State College, Pennsylvania.

On September 15, we received from Mr. Rendle twelve young homing pigeons trained around the compass fifty miles from Cozad. The following day they were released in groups of three, at Berkeley Springs, Virginia. Inspection of Pennsylvania Map IV shows the total flight vector for the six reported: one stayed at or returned to Berkeley Springs but none followed a flight line more than $60^{\circ}$ or so from the total flight vector, itself in a correct direction, and terminating within ten miles of the same Coriolis line through Cozad. This Cozad, Nebraska, to Pennsylvania result is a corroboration of the strongly indicative State College, Pennsylvania, Kearney, Nebraska, results.

Shortly before receiving these young Cozad birds Mr. Rendle shipped 10 old birds which had had 200 to 400 mile flights in their records. These were released at various places one hundred miles or more from the center of Pennsylvania. Closely paralleling Mr. Rendle's own predictions three of these birds homed across the 1400 or more miles to Cozad in from one to three weeks. Finally three of the remaining ones were reported found in the region of Michigan, western Pennsylvania, and eastern Ohio. A full discussion of these results requires more space than is available here and will appear in a later paper.

\section{Salient Points of the First Nebraska Experimental Results}

1. Of one-hundred twenty-two birds trained in State College and released in Nebraska, only one was ever reported east of Indiana. This was telegraphed in eight months later from Phillipsburg, Pennsylvania.

2. Of the eight main Nebraska releases, six of the total flight vectors support the validity of the theory, in addition to the indicative results obtained with the Cozad, Nebraska birds flown from south of Pennsylvania.

3. The Askania magnetometer readings on a sixty-mile line indicate there are two rather than one magnetic vertical-Coriolis conjugates in the Kearney, Nebraska, region. Two groups of total flight vectors (Special No. 1 together with Nos.
4,5 , and 8) and (Nos. 1 and 2), also show this to be true.

4. Two birds, one from seventy, the other from one-hundred eighty miles, flew in directions almost exactly opposite to their home area in State College, Pennsylvania, and found their lofts at the predicted conjugate point. An additional bird was found within three miles of the west conjugate and three were reported within less than ten miles of the anomalous conjugate point. Considering the fact that a homing pigeon should be familiar with landmarks twenty-five miles out from its home loft in order to assure a successful flight termination, it is evident that six of the reported birds (see data on releases Nos. 1-2 and 3, 4-4, 5-1, 8-1, Special No. 1-1) performed the equivalent of "homing" at their conjugate points. It is probable that a high percent of those used in the experiment flew into the regions involved, but, not seeing the loft or familiar landmarks, flew out again in random directions.

5. The results were good in the face of many adverse factors acting against success, such as:

(a) The birds were trained in green mountainous country but the experimental flights were over flat, brown terrain.

(b) The limited supply of five-foot signal balloons used in piloting the birds at the home loft were quickly blown down and punctured on stones during the first few minutes in the air during the first two days in Nebraska so their use had to be abandoned.

(c) The experimental flights were executed in hot, dry winds of from sixteen to forty-eight miles per hour velocity which blew continuously during the day. Experienced racing-pigeon men fear any wind velocities above twelve miles per hour even at normal temperatures. This was in direct contrast to low velocity winds or complete absence of winds during the training period in Pennsylvania.

(d) The birds of necessity were always liberated after 1:00 P.M., because of inadequate help and transportation. This is late in the day for the most successful flying and navigating results.

(e) Experience has shown the longer experimental flight to be more successful. Over-caution, especially at the beginning of the undertaking, 
Table IV.

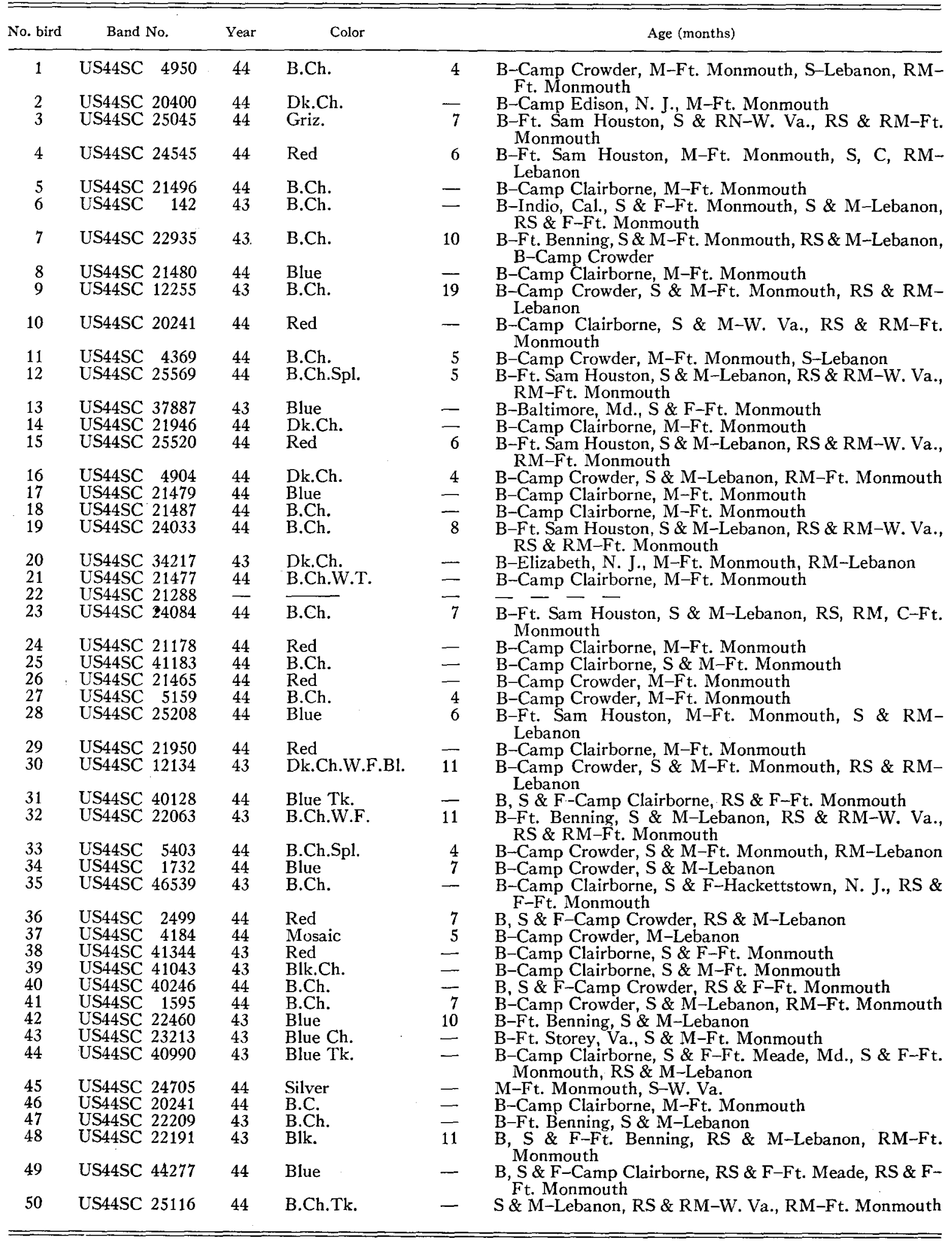




\section{Glossary to Table IV}

Bred (B)-includes mating of old birds, hatching and raising youngsters to flying stage (about four and one-half weeks or longer), but without any flying outside of the loft confines.

Settled (S)-involves letting birds fly outside of loft for the first time. Youngsters up to five or six weeks of age can be settled at a new loft, any distance whatever from the home cote, twenty-four hours after arrival.

Resettled (RS)-repeating operation (S) at a new loft or loft location. The Army was able to do this in seven or eight days by mobiling the birds at the initial settling station.

Flown (F) - this means that, in addition to regular daily exercise flights from the loft, the birds are each day released at progressively greater distances from the home location. Flights of under twenty-five miles are for the

caused us to keep the release distances on the short side.

At the completion of the first tests of the bird navigation theory just described, the data obtained were examined critically by the statistical group at the Iowa State College. These men, under Dr. George W. Snedecor, recommended that, in view of the indicative results, work should be continued and more data should be obtained. With this object in view plans with newly suggested procedures were carried out which resulted in the following experiments.

\section{EXPERIMENT III}

\section{Hamlet Experiment, September 1944}

The writer has talked to many persons, with much experience in racing homing pigeons, who contend that birds have a mysterious power to retrace a path over which they have been carried, even in darkness or in a drugged condition. Some tests of this contention ${ }^{13}$ have been made and negative results obtained. There are also many experienced pigeon-racing men who claim that homing pigeons possess the remarkable ability to return to a loft from a distance, merely by virtue of their having lived in it. In the experiment of June, 1944, already recorded, the birds used in "Special release No. 2," had neither flying experience around their home loft at State College, Pennsylvania, nor navigational training.

${ }^{13} \mathrm{G}$. Reynaud, "The laws of orientation among animals," Smith. Inst. Ann. Report of Board of Directors, p. 481, (translated from Rev. des Deux Mondes 146) 380 (1898), also O. H. Mowrer, J. compar. Psychol. 19, 177 (1935). purpose of giving them knowledge of local landmarks for piloting to the exact loft locations, plus knowledge of magnitude and gradients of the directives for later use in navigating over unfamiliar territory.

Mobiled (M) - after settling to a portable loft, the latter is moved each day so birds, in their local flying and short training flights, search for it rather than for a particular spot on the land. In military mobiling operations the loft transfers are along a straight line. In the training operations of these experiments the successive locations were always on a circuitous route.

Remobiled (RM) - after settling and mobiling in a given region the birds are resettled, with the same or similar appearing portable lofts, at any desired distance from the last location. In the war, birds were mobiled in this country and remobiled in the European and Pacific war theatres.

Although the data are far too limited to be conclusive, they do indicate an inability of such birds to make any effective attempt whatever at homing.

At the close of the first full-scale experiment in Nebraska it was found possible to secure, from mobile lofts of the Army Signal Corps at Fort Monmouth, New Jersey, three hundred pigeons, which (with one exception, as later learned) had had no training in navigation, although some had had limited "pilotage" experience from being settled and flown from short distances at the lofts where they were bred. These birds were bred and shipped from Fort Sam Houston, Texas, Camp Crowder, Missouri, and other stations indicated in Table IV and had been given only "mobile" training at Fort Monmouth. Upon arrival at the experimental headquarters at Hamlet, Nebraska, on September 29, 1944, they were placed in Army mobile lofts and permitted a twenty-four-hour rest before being transferred to the various release points. In order to take care of the slight possibility that they might be able to navigate even with the various types of training indicated, the releases were arranged from locations within a hundred and fifty miles radius of Hamlet, Nebraska. The latter is practically on the conjugate point for Fort Monmouth, New Jersey, and according to the theory and the Kearney, Nebraska, results, the point toward which the birds would fly, should their limited Fort Monmouth mobile training be adequate. On September 30, 1944, two hundred and fifty of these birds were re- 
TABLE V.

\begin{tabular}{|c|c|c|c|c|}
\hline Bird No. & Date & Place released & Place found & Distance traveled \\
\hline \multicolumn{5}{|c|}{ Group No. 1} \\
\hline 1 & Sept. 30,1944 & Ansley & Ansley & 0 miles \\
\hline 2 & Sept. 30,1944 & $8 \mathrm{mi}$. E. Goodland & $5 \frac{1}{2} \mathrm{mi}$. E. Selden & $60^{\circ}$ \\
\hline 3 & Sept. 30,1944 & Between Quinter and Ellis & Between Quinter and Ellis & 0 \\
\hline 4 & Sept. 30, 1944 & $9 \mathrm{mi}$. W. Burlington & $5 \mathrm{mi}$. N.E. Kit Carson & 40 \\
\hline 5 & Sept. 30,1944 & $17 \mathrm{mi}$. E. Goodland & $17 \mathrm{mi}$. S.W. Burlington & 55 \\
\hline 6 & Sept. 30,1944 & Miller & Miller & 0 \\
\hline 7 & Sept. 30,1944 & 13 mi. S. Alma & Alton, Kan. & 40 \\
\hline 8 & Sept. 30,1944 & $3 \mathrm{mi}$. W. Bur. Stratton & $3 \mathrm{mi}$. W. Bur. Stratton & 0 \\
\hline 9 & Sept. 30, 1944 & Phillipsburg, Kan. & Stocton S.E. & 23 \\
\hline 10 & Sept. 30,1944 & Ansley & Ansley & 0 \\
\hline 11 & Sept. 30,1944 & Miller & Holstein & 50 \\
\hline 12 & Sept. 30,1944 & $21 \mathrm{mi}$. E. Quinter & 7 mi.S.W. Waukaneg, Kan. & 7 \\
\hline 13 & Sept. 30,1944 & 3 mi. E. Goodland & Goodland & 3 \\
\hline 14 & Sept. 30,1944 & $5 \mathrm{mi}$. E. Goodland & Winona & 30 \\
\hline 15 & Sept. 30,1944 & $6 \mathrm{mi} . \mathrm{N}$. Ansley & $4 \mathrm{mi}$. S.E. Broken Bow & 11 \\
\hline 16 & Sept. 30,1944 & 6 mi. E. Quinter & $20 \mathrm{mi}$. S.E. Grainfield & 17 \\
\hline 17 & Sept. 30,1944 & Goodland, Kan. & Goodland, Kan. & 0 \\
\hline 18 & Sept. 30,1944 & $12 \mathrm{mi}$. N. Ansley & $4 \mathrm{mi}$. N. Wood River & 58 \\
\hline 19 & Sept. 30,1944 & Quinter & Quinter & 0 \\
\hline 20 & Sept. 30,1944 & $23 \mathrm{mi}$. N. Miller & York, Neb. & 100 \\
\hline 21 & Sept. 30,1944 & 3 mi. N. Phillipsburg & 4 mi. N. Phillipsburg & 1 \\
\hline 22 & Sept. 30, 1944 & Phillipsburg & Phillipsburg & 0 \\
\hline 24 & Sept. 30,1944 & $5 \mathrm{mi} . \mathrm{N}$. Miller & Juniata & 50 \\
\hline 25 & Sept. 30,1944 & Goodland & Goodland & 0 \\
\hline 26 & Sept. 30,1944 & $17 \mathrm{mi}$. E. Goodland & $8 \mathrm{mi}$. S. Monument & 32 \\
\hline 27 & Sept. 30,1944 & 14 mi. S. Miller & Elm Creek & 30 \\
\hline 28 & Sept. 30,1944 & $3 \mathrm{mi}$. W. Burlington & W. Eckley, Col. & 57 \\
\hline 29 & Sept. 30,1944 & $20 \mathrm{mi}$. E. Goodland & $19 \mathrm{mi} . \mathrm{E}$. Goodland & 1 \\
\hline 30 & Sept. 30,1944 & Alma & E. Alma & 1 \\
\hline 32 & Sept. 30,1944 & Ellis, Kan. & Ellis, Kan. & 0 \\
\hline 33 & Sept. 30,1944 & $18 \mathrm{mi}$. N. Ansley & $8 \mathrm{mi}$. N.E. Broken Bow & 7 \\
\hline 34 & Sept. 30,1944 & Burlington & Burlington & 0 \\
\hline 35 & Sept. 30,1944 & Ogalla & Ogalla & 0 \\
\hline 37 & Sept. 30,1944 & $6 \mathrm{mi}$. E. Quinter & $11 \mathrm{mi}$. S.W. Stockton & 47 \\
\hline 38 & Sept. 30,1944 & $18 \mathrm{mi} . \mathrm{E}$. Waukeeny & Bazine, Kan. & 40 \\
\hline 39 & Sept. 30,1944 & $3 \mathrm{mi}$. S. Alma & Republican City & 0 \\
\hline 41 & Sept. 30,1944 & $12 \mathrm{mi}, \mathrm{E}$. Quinter & 5 mi. N.E. McCracken & 40 \\
\hline 42 & Sept. 30,1944 & Waukeeny & Utica & 30 \\
\hline 43 & Sept. 30,1944 & $11 \mathrm{mi} . \mathrm{N}$. Miller & $1 \mathrm{mi}$. W. Heartwell & 48 \\
\hline 44 & Sept. 30,1944 & $6 \mathrm{mi} . \mathrm{W}$. Burlington & Stratton, Col. & 19 \\
\hline 45 & Sept. 30,1944 & $3 \mathrm{mi}$. W. Burlington & $10 \mathrm{mi} . \mathrm{W}$. Burlington & 7 \\
\hline 46 & Sept. 30,1944 & Ansley & Ansley & 0 \\
\hline \multirow{3}{*}{$\begin{array}{l}47 \\
50\end{array}$} & Sept. 30,1944 & Ellis, Kan. & Ellis, Kan. & 0 \\
\hline & Sept. 30,1944 & Alma & Alma & 0 \\
\hline & & & $\operatorname{oup~No.2}$ & \\
\hline \multirow[t]{3}{*}{23} & Sept. 30,1944 & Goodland, Kan. & 7 mi. E. Wallace, Neb. & 110 (navigating experience at \\
\hline & & & & Ft. Monmouth. Flew to- \\
\hline & \multicolumn{4}{|c|}{ Group No. 3} \\
\hline 31 & Sept. 30,1944 & 9 mi. W. Burlington & 30 mi. N.E. Garden City, & \\
\hline 36 & Sept. 30,1944 & $12 \mathrm{mi} . \mathrm{S}$. Alma & 16 mi. N. Great Bend, Kan. & 115 (made long flights in gen- \\
\hline 40 & Sept. 30,1944 & $15 \mathrm{mi}$. E. Ouinter & Sharon & tion of place bred) \\
\hline 48 & Sept. 30,1944 & $9 \mathrm{mi}$. N. Phillinsburg & $3 \mathrm{ml}, \mathrm{W}$. Rozel & 110 \\
\hline 49 & Sept. 30,1944 & Phillipsburg, Kan. & Haviland, Kan. & 145 \\
\hline & & N & ess otherwise specified) & \\
\hline
\end{tabular}

leased in four groups near Goodland, Kansas, Miller, Nebraska, Alma, Nebraska, and Quinter, Kansas, respectively. Small groups of twos, threes, fours, and fives were released, ten minutes apart, beginning at dawn. The weather was cool and clear with gusty winds of about fifteen miles per hour blowing during the day. Of two hundred and fifty birds released, fifty-four were reported on or before October 30 , by telegrams. ${ }^{14}$

14 Of the remaining fifty of the original three hundred, half were youngsters, the others yearlings. The twenty-five yearlings were released at Culbertson in a group most of 
The performance of the birds released, as indicated by the telegrams reporting the flight terminals, seems to divide them into three natural groups (Table V) each of which will be dealt with separately.

\section{Results}

Group No. 1. These forty-eight birds flew in short random flights ranging from zero to sixty miles from the points of release. The arithmetical average of the forty-eight flights is about twenty miles. Of these, twenty were reported within a mile of the release point. An even more significant indication about the flight of these birds is that the average of the vector sum of their flight vectors (previously referred to as the "total flight vector") is less than ten miles. Since these flights, including distance and directions, are vector quantities, the vector sum and its average is the only one which has real meaning in this connection.

Group No. 2. This 110-mile flight seems significant in that this bird flew in a direct line for Hamlet, Nebraska, which is the conjugate point of Fort Monmouth, New Jersey, and stopped just thirty miles beyond. Of the fifty-two birds reported, it is the only one which had had the proper training in navigating to do this. It was later learned that it had been used in communications at Fort Monmouth, New Jersey, and inadvertently was shipped with the less experienced birds.

Group No. 3. These five birds are distinguished from the rest in that they made long flights averaging one hundred and fifteen miles in length, in addition to flying in directions quite accurately toward their original homes which are as follows:

\begin{tabular}{cl} 
Bird No. & \multicolumn{1}{c}{ Place bred } \\
31 & Camp Clairborne, Louisiana \\
36 & Camp Crowder, Missouri \\
41 & Camp Crowder, Missouri \\
50 & Cort Benning, Georgia \\
51 & Camp Clairborne, Louisiana \\
\hline
\end{tabular}

A check made with the head of the Army Pigeon

which took up residence on the spot. The twenty-five youngsters were retained for "navigation" training at State College, Pennsylvania, for later experimentation.
Service revealed that they had been settled and had had considerable flying experience around their home loft before being shipped to Fort Monmouth, New Jersey, which may account not only for the length but also the direction of their flights.

It should be noted that any one of the fifty reported birds, having been bred from some of the world's finest homing pigeons, had the inherited qualities and the mental and physical make-up to fly a like distance toward Fort Monmouth or its conjugate point had they also possessed the means of so doing, brought about by the required type of navigational training. If the "retracement" contention had credence, they should have flown back along the path over which they had been transported by train two days before, or retraced the paths over which they had been taken by car from Hamlet to the various release points, during the hours previous to their release. In the latter case they should have flown toward Hamlet first and then started eastward to Fort Monmouth instead of the short random flights in forty'-seven of fiftyfour reported cases.

It is a well established fact that homing pigeons settled and trained to navigate at any point, will, in most cases, if physically able, return to it when released moderate distances away, such as one to three hundred miles. This experiment indicates, however, that just settling $^{15}$ and mobiling will not replace the training in navigation which they must have to home successfully from a distance. It therefore seems evident, whereas they may inherit the ability to navigate, that they must first have specialized and adequate training in order to accomplish it.

The results of the Hamlet experiment and Special No. 2 and all other tests of these experiments, indicate that homing pigeons do not retrace paths over which they have just been transported unless these latter happen to be directly in line from the home (or its conjugate point) to which they have been trained to pilot and to navigate.

\footnotetext{
${ }^{15}$ See explanation in Glossary appended to Table IV. Explains training which they must have to home successfully from a distance. It therefore seems evident, whereas they may inherit the ability to navigate, that they must first have specialized and adequate training in order to accomplish it.
} 
TABLE VI. Showing release and terminal points of birds reported or which returned to the home loft at State College, Pennsylvania. Releases by Major Otto Meyer, Lt. A. M. Lehman, Dr. P. F. English, Jack Nesbitt, Roy Johnson, Donald Brenner, H. L. Yeagley, Dr. George $O$. Hendrickson. (X)-Birds released within 100 miles of the line of tangency and crossed over. E-Birds released east of line of tangency. W-Birds released west of line of tangency.

\begin{tabular}{|c|c|c|c|c|c|c|}
\hline $\begin{array}{l}\text { Yellow } \\
\text { band } \\
\text { number }\end{array}$ & $\begin{array}{l}\text { U. S. Army } \\
\text { Signal Corps } \\
\text { band No. }\end{array}$ & $\begin{array}{c}\begin{array}{c}\text { Place of } \\
\text { release }\end{array} \\
\end{array}$ & Date & Place found & Date & Designation \\
\hline 201 & US45SC 68367 & Marshaltown, Iowa & $6 / 12$ & $\begin{array}{l}11 \mathrm{mi} \text {. E. of Sious } \\
\text { Falls, S. D. }\end{array}$ & $6 / 14$ & W \\
\hline 202 & US45SC 68272 & Joliet, Ill. & $6 / 11$ & La Salle, Ill. & $6 / 16$ & (X) \\
\hline 203 & US45SC 68390 & Arlington, Neb. & $6 / 12$ & Nebraska City, Neb. & $6 / 14$ & $W$ \\
\hline 204 & US45SC 68300 & Ames, Iowa & $6 / 12$ & Tennanet, Iowa & $6 / 25$ & 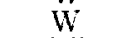 \\
\hline 205 & US45SC 68345 & Morrison, Ill. & $6 / 14$ & Marion, Ind. & $6 / 14$ & $(X)$ \\
\hline & US45SC 68343 & Cedar Rapids, Iowa & $6 / 12$ & Casey, Iowa & $6 / 14$ & $\mathrm{~W}^{\prime}$ \\
\hline $\begin{array}{l}207 \\
208\end{array}$ & $\begin{array}{l}\text { US45SC } 68352 \\
\text { US45SC } 68350\end{array}$ & & $6 / 12$ & Not reported & & \\
\hline & $\begin{array}{ll}\text { US45SC } & 68350 \\
\text { US45SC } & 68355\end{array}$ & $\begin{array}{l}\text { Arlington, Neb. } \\
\text { Morrison, Ill. }\end{array}$ & $\begin{array}{l}6 / 12 \\
6 / 11\end{array}$ & Not reported & & \\
\hline 210 & $\begin{array}{ll}\text { US45SC } & 68355 \\
\text { US45SC } 68392\end{array}$ & Tiffin, Ohio & $\begin{array}{l}6 / 11 \\
6 / 11\end{array}$ & $\begin{array}{l}\text { Gridley, Ill. } \\
\text { Not reported }\end{array}$ & $7 / 3$ & (X) \\
\hline 211 & US45SC 68368 & Wadsworth, Ohis & $6 / 10$ & State College, Pa. & $6 / 20$ & $\mathrm{E}$ \\
\hline 212 & US45SC 68369 & Carroll, Iowa & $6 / 12$ & Stuart, Iowa & $6 / 24$ & W \\
\hline 213 & US45SC 68356 & Carroll, Iowa & $6 / 12$ & Not reported & & \\
\hline 214 & US45SC 68380 & Uunlap, Iowa & $6 / 14$ & Fontanelle, Neb. & $6 / 14$ & W \\
\hline $\begin{array}{l}215 \\
216\end{array}$ & $\begin{array}{l}\text { US45SC } 68389 \\
\text { US4 } 5 \text { SC } 68354\end{array}$ & Altoona, $\mathrm{Pa}$. & $\begin{array}{l}6 / 10 \\
6 / 11\end{array}$ & State College, $\mathrm{Pa}$. & $6 / 10$ & $\mathrm{E}$ \\
\hline 217 & US45SC 68382 & $\begin{array}{l}\text { Tiffin, Ohio } \\
\text { Cedar Rapids, Iowa }\end{array}$ & $\begin{array}{l}6 / 11 \\
6 / 12\end{array}$ & Not reported & $0 / 14$ & $\mathbf{E}$ \\
\hline 218 & US45SC 68185 & Arlington, Neb. & $6 / 12$ & Not reported & - & \\
\hline 219 & US45SC 68239 & Ottowa, Ohio & $6 / 11$ & Not reported & & \\
\hline 220 & US45SC 68351 & Arlington, Neb. & $6 / 12$ & Not reported & & \\
\hline $\begin{array}{l}221 \\
222\end{array}$ & US45SC 68344 & Valparizo, Ind. & $6 / 11$ & Not reported & & \\
\hline $\begin{array}{l}222 \\
223\end{array}$ & $\begin{array}{l}\text { US45SC } 68341 \\
\text { US45SC } 68372\end{array}$ & Joliet, Ill. & $6 / 11$ & Not reported & & \\
\hline 224 & $\begin{array}{l}\text { US45SC } 68372 \\
\text { US45SC } 68353\end{array}$ & Youngstown, Ohio & $6 / 10$ & Loyalhanna, Pa. & $6 / 11$ & $E$ \\
\hline 225 & $\begin{array}{l}\text { US45SC } 08353 \\
\text { US45SC } 68364\end{array}$ & $\begin{array}{l}\text { Carroll, lowa } \\
\text { Van Wert, Ohio }\end{array}$ & $\begin{array}{l}0 / 12 \\
6 / 11\end{array}$ & $\begin{array}{l}\text { Coon Rapids, lowa } \\
\text { Not reported }\end{array}$ & $6 / 14$ & W \\
\hline 226 & US45SC 68391 & Waterman, Ill. & $6 / 11$ & Mt. Ayr, Iowa & $6 / 14$ & $W$ \\
\hline 227 & US45SC 68362 & Butler, $\mathrm{Pa}$. & $6 / 10$ & State College, Pa. & $6 / 10$ & $\mathbf{E}$ \\
\hline 228 & US45SC 68381 & Youngstown, Ohio & $6 / 10$ & State College, $\mathrm{Pa}$. & $6 / 11$ & $\mathrm{E}$ \\
\hline 229 & US45SC 68385 & Indiana, $\mathrm{Pa}$ : & $6 / 10$ & Johnstown, Pa. & $6 / 12$ & $\mathrm{E}$ \\
\hline 230 & US45SC 68363 & Ottowa, Ohio & $6 / 11$ & Weirton, W. Va. & $6 / 20$ & $\mathrm{E}$ \\
\hline $\begin{array}{l}231 \\
232\end{array}$ & US45SC 68377 & Waterman, Ill. & $6 / 12$ & Chariton, lowa & $6 / 12$ & $W$ \\
\hline $\begin{array}{l}2.52 \\
233\end{array}$ & $\begin{array}{l}\text { US45SC } 68273 \\
\text { US45SC } 68304\end{array}$ & Arlington, Neb. & $\begin{array}{l}0 / 12 \\
6 / 11\end{array}$ & Garland, Neb. & $6 / 20$ & (X) \\
\hline 234 & US45SC 68393 & $\begin{array}{l}\text { Butler, Pa. } \\
\text { Bud. }\end{array}$ & $6 / 10$ & Cowansville, Pa. & $6 / 18$ & E \\
\hline 235 & US45SC 68141 & Marshaltown, Iowa & $6 / 13$ & Boxholm, Iowa & $6 / 15$ & W \\
\hline 236 & US45SC 68347 & Indiana, Pa. & $6 / 10^{\circ}$ & Gibsonia, $\mathrm{Pa}$. & $6 / 19$ & $\mathrm{E}$ \\
\hline 237 & US45SC 68302 & Not released & No record & & & \\
\hline 238 & US45SC 68388 & Ames, Iowa & $6 / 12$ & Not reported & & \\
\hline 239 & US45SC 68348 & Wadsworth, Ohio & $6 / 10$ & Northfield, Ohio & $6 / 11$ & $\mathrm{E}$ \\
\hline 240 & US45SC 68349 & Altoona, $\mathrm{Pa}$. & $6 / 10$ & State College, $\mathrm{Pa}$. & $6 / 10$ & $\mathrm{E}$ \\
\hline 241 & US45SC 68387 & Dunlap, Iowa & $6 / 12$ & Dow City, Iowa & $6 / 14$ & W \\
\hline 242 & US45SC 68386 & Not reported. & & & & \\
\hline
\end{tabular}

\section{EXPERIMENT IV}

\section{The East-West Experiment, June 1945}

As previously stated, the orientation of the magnetic-vertical lines with respect to the Coriolis lines produce regions where the gridwork character tapers off and a pattern of irregular parallelism or tangency occurs. Reference to Map II indicates this relationship over a fairly wide strip of land through the region which includes the states of Wisconsin, Illinois, Indiana, Kentucky and continuing in a south-south-east direction. An irregular line including all the points of tangency in this region will subsequently be referred to as "the line of tangency."

It seems evident that if birds are guided to a unique point (their home or conjugate point) by conditions requiring grid representations of the fields of influence, they would lack that guidance in a region where the indicating lines approximate a condition of parallelism. Such has been thought to be the case by racing pigeon men in the region just referred to. ${ }^{16}$ The procedures of

${ }^{16}$ F. J. Sauerteig, "Indianapolis," Am. Racing Pigeon News (November 1942). 
TABLE VII. Showing classifications of birds with regard to their releases east and west of line of tangency (including those released within 100 miles of this line).

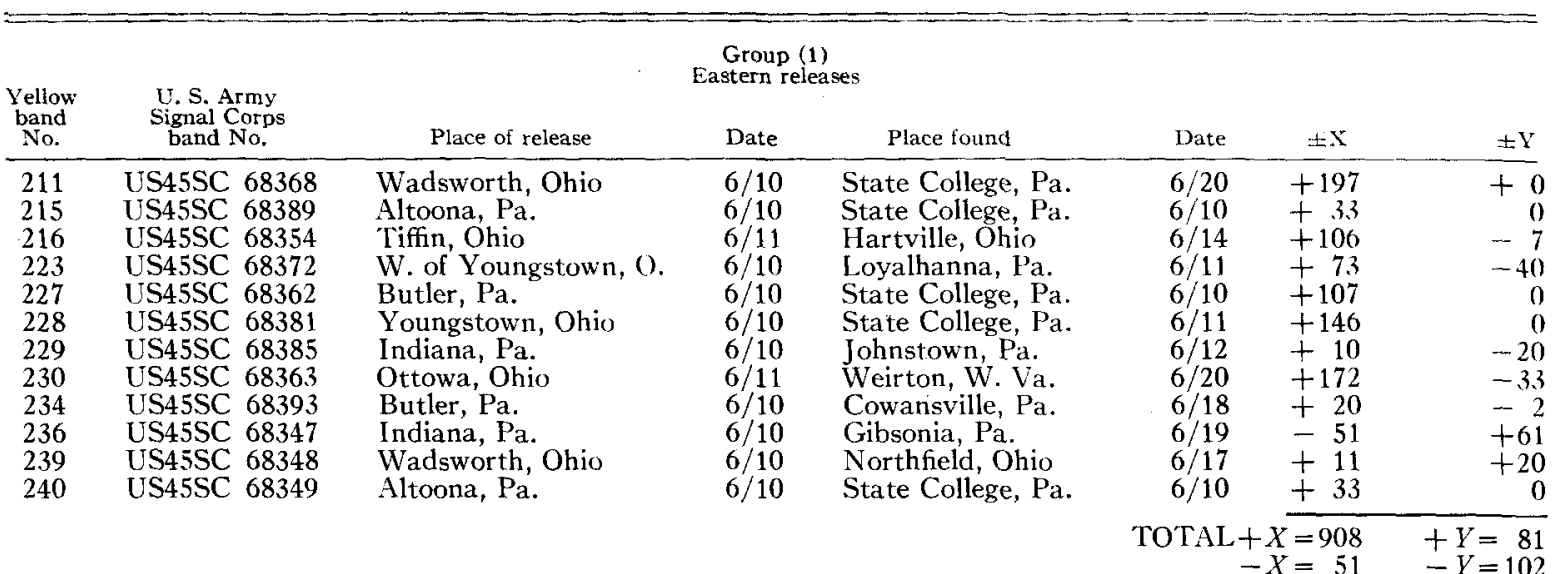

\begin{tabular}{|c|c|c|c|c|c|c|c|}
\hline \multicolumn{8}{|c|}{$\begin{array}{c}\text { Group (2) } \\
\text { Western releases }\end{array}$} \\
\hline 201 & US45SC 68367 & Marshaltown, Iowa & $6 / 12$ & $\begin{array}{l}11 \text { mi. East of Sioux } \\
\text { Falls, S. D. }\end{array}$ & $6 / 14$ & +165 & -140 \\
\hline 203 & US45SC 68390 & Arlington, Neb. & $6 / 14$ & Nebraska City, Neb. & $6 / 14$ & -8 & +57 \\
\hline 204 & US45SC 68300 & Ames, Iowa & $6 / 12$ & Tennant, Iowa & $6 / 25$ & +92 & +4 \\
\hline 206 & US45SC 68343 & Cedar Rapids, Iowa & $6 / 12$ & Casey, Iowa & $6 / 14$ & +143 & +8 \\
\hline 212 & IS45SC 68369 & Carroll, Iowa & $6 / 12$ & Stuart, Iowa & $6 / 24$ & -14 & +42 \\
\hline 214 & US45SC 68380 & Dunlap, Iowa & $6 / 12$ & Fontanelle, Neb. & $6 / 14$ & +45 & +4 \\
\hline 224 & US45SC 68353 & Carroll, Iowa & $6 / 12$ & Coon Rapids, Iowa & $6 / 14$ & -4 & +12 \\
\hline 226 & US45SC 68391 & Waterman, Ill. & $6 / 11$ & Mt. Ayr, Iowa & $6 / 14$ & +280 & +45 \\
\hline 231 & US45SC 68377 & Waterman, Ill. & $6 / 11$ & Chariton, Iowa & $6 / 12$ & +232 & +30 \\
\hline 232 & US45SC 68273 & Arlington, Neb. & $6 / 12$ & Garland, Neb. & $6 / 26$ & +41 & +22 \\
\hline 235 & US45SC 68141 & Marshaltown, Iowa & $6 / 12$ & Boxholm, Iowa & $6 / 15$ & +52 & -20 \\
\hline \multirow[t]{2}{*}{241} & US45SC 68387 & Dunlap, Iowa & $6 / 12$ & Dow City, Iowa & $6 / 14$ & & miles \\
\hline & . & & & & \multicolumn{2}{|c|}{$\begin{array}{rr}\text { TOTAL }+X=1050 \\
-X=26\end{array}$} & $\begin{array}{l}+Y=224 \\
-Y=160\end{array}$ \\
\hline \multicolumn{8}{|c|}{$\begin{array}{c}\text { Group (3) } \\
\text { Birds released within } 100 \text { miles of line of tangency }\end{array}$} \\
\hline \multirow{5}{*}{$\begin{array}{l}202 \\
205 \\
209 \\
233\end{array}$} & US45SC 68272 & Joliet, III. & $6 / 11$ & LaSalle, Ill. & $6 / 16$ & +50 & $\overline{+12}$ \\
\hline & US45SC 68345 & Morrison, Ill. & $6 / 11$ & Marion, Ind. & $6 / 14$ & +220 & -58 \\
\hline & US45SC 68355 & Morrison, Ill. & $6 / 11$ & Gridlev, Ill. & $7 / 3$ & +47 & -58 \\
\hline & US45SC 68394 & Valparizo, Ill. & $6 / 11$ & Kankakee, Ill. & $6 / 13$ & +30 & +18 \\
\hline & & & & & \multicolumn{2}{|c|}{$\begin{aligned} \text { TOTAL }+X & =347 \\
-X & =-0\end{aligned}$} & $\begin{array}{l}+Y=+30 \\
-Y=-116\end{array}$ \\
\hline
\end{tabular}

this experiment were designed to test this phase of the theory.

On April 23, 1945, fifty five-week old youngsters were received from Fort Sam Houston, Texas. Pilotage and navigation training of these birds was started immediately. Their loft was not mobiled and training releases were made twice daily. These consisted of one, two, four, eight, sixteen, and twenty-five mile flights for pilotage experience, and many thirty-, fifty-, and seventy-mile flights, in several directions, for navigational training. On some of the longer flights they were liberated in twos, threes, and fives to make them more self-reliant and capable of independent navigational flights.

On June 10, 1945, when the experiment was to begin, there remained forty-two birds. The other eight were lost in the longer training flights, especially when released in small groups. They were transported by truck from State College to the points of liberation which were about equally spaced between State College, Pennsylvania, and Kearney, Nebraska. Table VI shows the time and place these birds were released as well as the time and place each was found and reported. Table VII shows the release 
and terminal points of all the birds whose flight terminals were determined. These include all reported by telegraph and in the case of the eastern releases, five which actually arrived at the home loft. In addition it classifies them as follows:

Group 1-Those birds released east of the line of tangency (or region of confusion).

Group 2-Those birds released west of the line of tangency.

Group 3-Those birds which were released within a distance of one hundred miles east or west of the line of tangency and flew across it.

The column at the right on Table VII also shows the distances which each bird flew on a direct line "toward the conjugate for the "western" releases and toward the home loft in the case of the "eastern" releases. The $Y$ column shows the perpendicular distances flown either $(+)$ counterclockwise or $(-)$ clockwise from the direct line to conjugate or home point, respectively.

Table VIII shows the computation of results from the data on Table VII. The algebraic sums of the $X$ and $Y$ components of both groups were divided by the number of flights contributing to their totals. These values of ( $\Sigma X / \mathrm{No}$. flights) and ( $\Sigma Y /$ No. flights) were then added vectorily to determine the resultant "flight vector" for the group of birds involved.

As shown, the Eastern group (No. 1) on the average flew 1.8 miles in a counter-clockwise direction while averaging 71.4 miles toward the home (a deviation of approximately $1.0^{\circ}$ ) whereas the Western group (No. 2) deviated 5.8 miles in a clockwise direction while averaging 93.1 miles toward the conjugate point (a deviation of approximately $3.6^{\circ}$ ).

At the conjugate end of the experiment the birds, even without errors caused by large local magnetic anomalies, would be subject to errors of fifteen or twenty-five miles from the point, because of the natural errors of navigation to which they are subject. At the home end the pilotage training permits the bird, by means of local landmarks, to finish the last twenty-five or so miles of the journey to the loft. This probably accounts for the smaller angle of deviation for the eastern group.

Birds of group (No. 3) were deliberately' liberated within the central two hundred-mile band, which should be a region of confusion insofar as the theory is concerned. It seems significant that the only birds to cross over the line of tangency were released in this band. More data will be obtained to check this indication.

\section{EXPERIMENT V}

\section{Second Kearney Experiment, June 1945}

This experiment deals with approximately two hundred homing pigeons trained at State College, Pennsylvania. In general, the preparations and procedures were the same as described in the previous experiment at Kearney, Nebraska. However, since the results of the previous tests had so thoroughly dovetailed with the requirements of magnetic-vertical Coriolis theory, at the suggestion of Major Otto Meyer and Lt. Arthur M. Lehman of the Army Signal Corps, it was decided to put a handicap in the way of these birds in order to give the theory the acid test. The plan involved training the birds by releasing them always north-west of State College, but when testing them for the conjugate point in the Kearney, Nebraska, region, making the releases well toward the north-east. In many of the pigeon races greater speed results from having the birds fly and refly over familiar territory and many believe the birds' ability to return depends on visual cues resulting from this careful training in the same direction. ${ }^{17}$ Therefore, the significance of the above plane is selfevident.

During the first Kearney experiment in July 1944, five-foot meteorological balloons were used at State College and in Nebraska in an attempt to aid the birds in piloting the last ten or fifteen miles to the loft. The strong Nebraska winds, however, quickly blew them down and broke them so that their value was not determined. In this experiment eight-foot orange-colored boxkites were used for a similar purpose. The kites were flown during most of the training flights to the home loft at State College and during the two days the birds were released in Nebraska. Since no birds actually found the lofts this year, it is assumed that their effect was negligible.

17 Ralph Gundlach, "Field study of homing pigeons;" Lucian H. Warmer, "The present status of the problems of orientation and homing by birds:" "Homing pigeons a puzzle to science," Am. Weekly (June 3, 1945). 
TABLE VIII. Computations with diagrams of results.

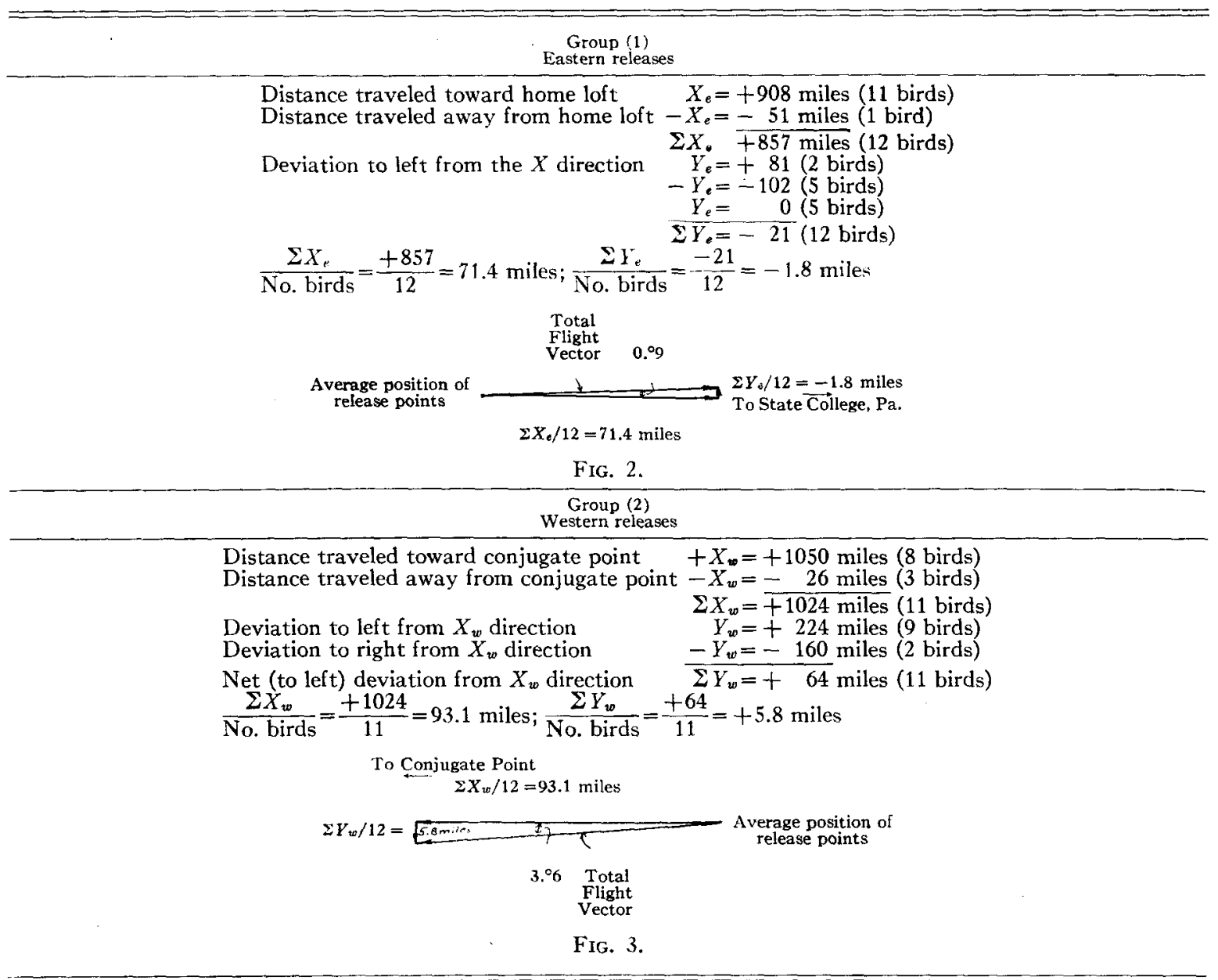

\section{Procurement and Training of Birds}

Of the two hundred homing pigeons trained for this experiment one hundred fifty-nine were six-week old youngsters supplied by the Army Service Forces from the Army breeding lofts at Fort Sam Houston, Texas. The remainder were birds secured from various racing pigeon men a year previous and held over to be used as twoyear-olds.

All the birds were housed in two mobile lofts having tall peaked roofs, six-foot ceilings, and six- by twelve-foot floor spaces. Each contained one hundred and twenty nest boxes with adequate avaries for sunning and bathing. The lofts were mounted on standard farm wagons having Timken high speed bearings, $6: 00 \times 16$ automobile tires, and were painted a bright yellow
They were moved one hundred yards twice daily for receiving the birds from their training flights. The latter change in loft position was accomplished with a Fordson farm tractor.

Training flights were carried out morning and afternoon. After the initial short flights to the east, north, and west, to take care of their error in navigation, the birds were trained only from the north-west. Except for a few stormy days, training was continuous from the time the younger birds were received on April 14 until the day of departure for Kearney on June 10.

The navigation flights were extended to seventy miles airline. The birds flew the latter distance many times and on several occasions, when the wind velocity was practically zero, they homed in approximately seventy minutes. 
TABLE IX.

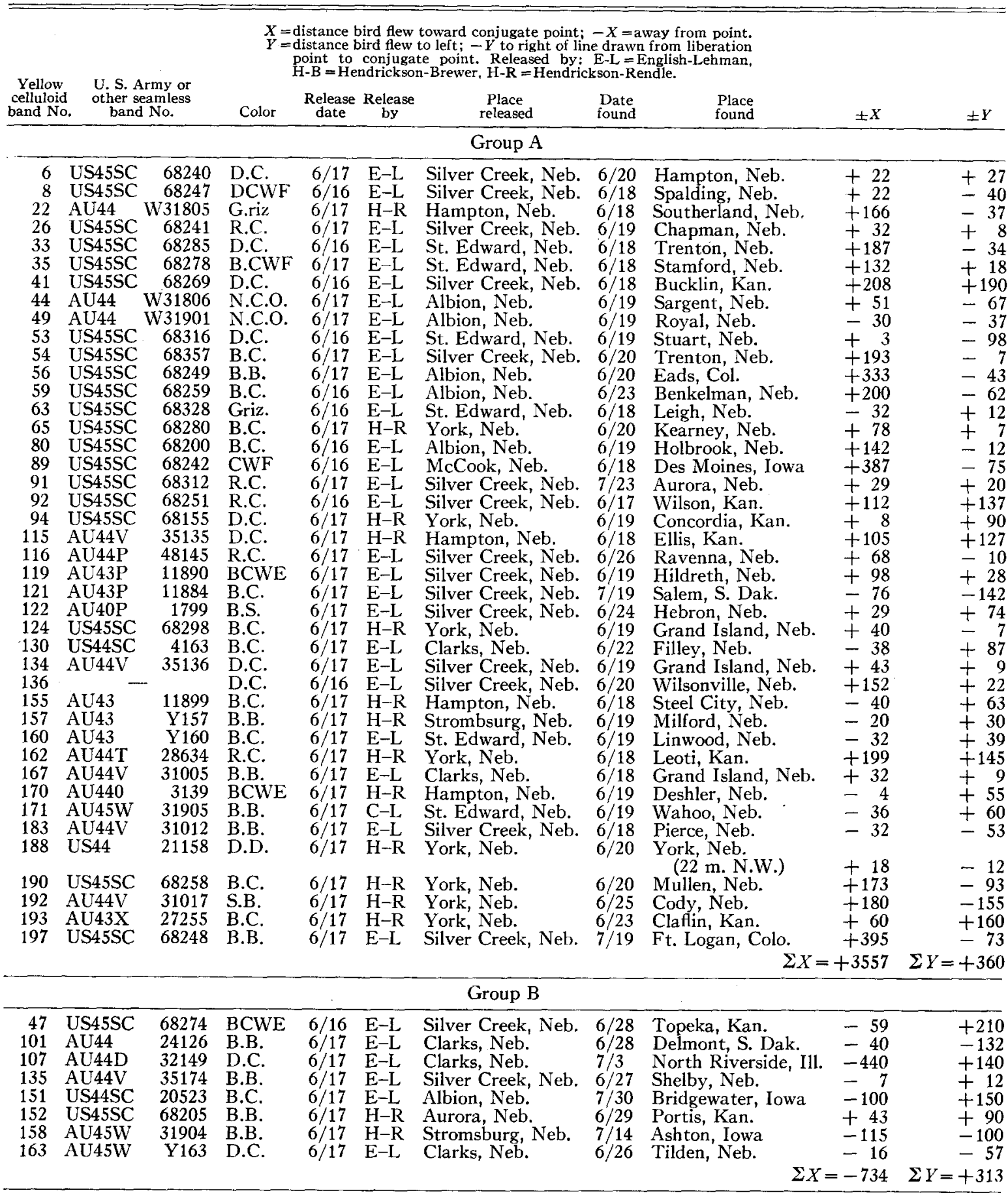

Training releases were made in groups of threes and fives a few times, but in most cases the birds were flown in groups of fifty.

On the morning of June 9th the birds were given a seven-mile exercise flight from the northwest. Immediately following, one of the lofts was transferred from its farm wagon base to a two-ton International Truck owned by the Agri- . 
TABLE IX.-Continued.

\begin{tabular}{|c|c|c|c|c|c|c|c|c|c|}
\hline \multirow[b]{2}{*}{$\begin{array}{c}\text { Yellow } \\
\text { celluloid } \\
\text { band No. }\end{array}$} & \multirow{2}{*}{\multicolumn{2}{|c|}{$\begin{array}{l}\text { U. S. Army or } \\
\text { other seamless } \\
\text { band No. }\end{array}$}} & \multicolumn{6}{|c|}{$\begin{array}{l}X=\text { distance hird flew toward conjugate point; }-X=\text { away from point. } \\
Y=\text { distance bird flew to left } ;-Y \text { to right of line drawn from liberation } \\
\text { point to conjugate point. Released by: E } \mathrm{L}=\text { English-Lehman, } \\
\text { H-B }=\text { Hendrickson-Brewer, H-R } \mathrm{H} \text {-Hendrickson-Rendle. }\end{array}$} & \multirow{3}{*}{ $\pm X$} \\
\hline & & & Color & $\begin{array}{c}\begin{array}{c}\text { Release } \\
\text { date }\end{array} \\
\end{array}$ & $\begin{array}{c}\text { Release } \\
\text { by }\end{array}$ & $\begin{array}{c}\text { Place } \\
\text { released }\end{array}$ & $\begin{array}{l}\text { Date } \\
\text { found }\end{array}$ & $\begin{array}{l}\text { Place } \\
\text { found }\end{array}$ & \\
\hline \multicolumn{9}{|c|}{ Group C } & \\
\hline $\begin{array}{r}10 \\
19 \\
32 \\
73 \\
78 \\
132 \\
141 \\
153 \\
199\end{array}$ & $\begin{array}{l}\text { AU444 } \\
\text { US45SC } \\
\text { US45SC } \\
\text { US45SC } \\
\text { US45SC } \\
\text { US45SC } \\
\text { US44SC } \\
\text { AU44V } \\
\text { AU44T }\end{array}$ & $\begin{array}{l}1475 \\
68287 \\
68289 \\
68295 \\
68297 \\
68157 \\
68275 \\
31015 \\
28631\end{array}$ & $\begin{array}{l}\text { D.C. } \\
\text { R. } \\
\text { S.B. } \\
\text { D.D. } \\
\text { B.C. } \\
\text { B.C. } \\
\text { R.C. } \\
\text { B.C. } \\
\text { B.C. }\end{array}$ & $\begin{array}{l}6 / 16 \\
6 / 17 \\
6 / 16 \\
6 / 19 \\
6 / 16 \\
6 / 17 \\
6 / 17 \\
6 / 17 \\
6 / 17\end{array}$ & $\begin{array}{l}\mathrm{H}-\mathrm{B} \\
\mathrm{H}-\mathrm{R} \\
\mathrm{E}-\mathrm{L} \\
\mathrm{H}-\mathrm{R} \\
\mathrm{H}-\mathrm{B} \\
\mathrm{E}-\mathrm{L} \\
\mathrm{E}-\mathrm{L} \\
\mathrm{H}-\mathrm{R} \\
\mathrm{H}-\mathrm{R}\end{array}$ & $\begin{array}{l}\text { McCook, Neb. } \\
\text { Stromsburg, Neb. } \\
\text { Silver Creek, Neb. } \\
\text { Stromsburg, Neb. } \\
\text { McCook, Neb. } \\
\text { Silver Creek, Neb. } \\
\text { St. Edward, Neb. } \\
\text { Hampton, Neb. } \\
\text { Stromsburg, Neb. }\end{array}$ & $\begin{array}{l}6 / 16 \\
6 / 24 \\
6 / 22 \\
6 / 22 \\
6 / 22 \\
9 / 19 \\
6 / 21 \\
6 / 21\end{array}$ & $\begin{array}{l}\text { McCook, Neb. } \\
\text { Stromsburg, Neb. } \\
\text { Genoa, Neb. } \\
\text { Stromsburg, Neb. } \\
\text { McCook, Neb. } \\
\text { Genoa, Neb. } \\
\text { Genoa, Neb. } \\
\text { Aurora, Neb. } \\
\text { Osceola, Neb. }\end{array}$ & $\begin{array}{c}0 \text { mile } \\
0 \text { mile } \\
10 \text { miles } \\
0 \text { mile } \\
0 \text { mile } \\
7 \text { miles } \\
10 \text { miles } \\
7 \text { miles } \\
10 \text { miles }\end{array}$ \\
\hline
\end{tabular}

cultural Engineering Department of the College. The second was coupled to the back of the truck. All feed, kites, and other needed equipment was put under a false floor built in the latter loft.

On June 10 th at 7 A.M. the trip to Kearney, Nebraska, was started. The party consisted of Roy Johnson, in charge of trucks, Jack Nesbitt, in charge of kites, Donald Brewer, in charge of birds, Major Otto Meyer, Lt. A. M. Lehman, P. F. English, and H. L. Yeagley. The trip of more than twelve hundred miles was made in three days. Two men, including the driver, handled the truck, and drivers were changed every two hundred or so miles, while the remainder of the party rode in a car belonging to the Pennsylvania Cooperative Wildlife Research Unit of the Pennsylvania State College and driven by Dr. English. At Ames, Iowa, Dr. George Hendrickson joined the party with a car owned by the Iowa Cooperative Research Unit. Mr. J. A. Rendle of Cozad, Nebraska, also joined the party at Kearney and assisted in the experimental procedures.

Upon arrival at Kearney the lofts were placed one and twenty miles, respectively, north of the town. This spaced them about equally north and south of the western State College conjugate. After one day for resting the birds, they were taken in groups and released on an average of seventy-five miles to the N.N.E. and E.N.E., and N.E. of the loft locations.

On June 15th at ten P.M. reports from the United States Weather Bureau indicated that the next day would be clear with scattered clouds and that wind velocities would average ten miles an hour or lower. About four o'clock the next morning (June 16th) Dr. English and Lt. Lehman took one hundred eighteen birds for liberation at points averaging seventy-five miles to the north-east of the conjugate. The birds were all released during the morning groups of threes and fives in the regions around the

TABLE $X$.




TABLE XI. Showing flight vectors, $X$ and $Y$ distances flown $\Sigma X$ and $\Sigma Y$ values and "total flight vector" for all Army pigeons reported within ten days of liberation. Number reported-20.

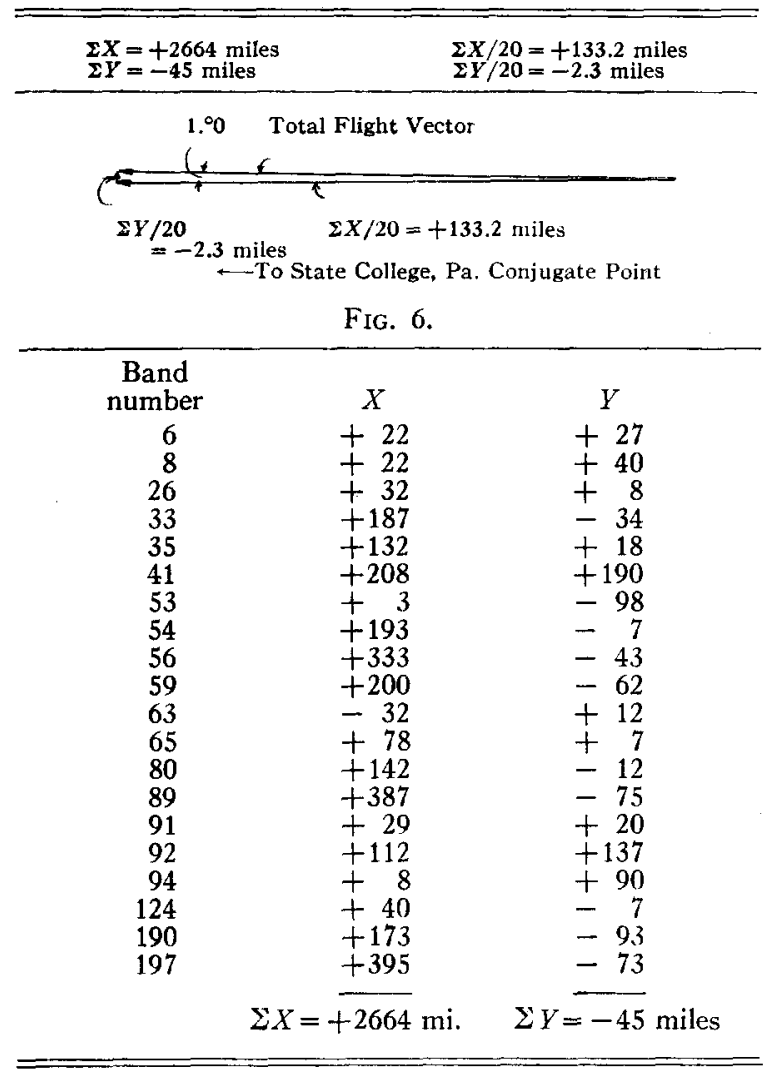

Nebraska towns of Clarks, Silver Creek, St. Edward, and Albion. Simultaneously Dr. Hendrickson and Donald Brewer released ten birds to the south-west (near McCook, Nebraska) for control purposes. As indicated by the weather reports, the day was unusually good for bird navigation.

The next morning, June 17 th, with weather report and actual weather similar to that of the preceding day, Dr. Hendrickson and Mr. Rendle took the fifty-six remaining birds for liberation to regions around Stromsburg, York, and Hampton, Nebraska. The distance was about the same as the preceding day but the direction was more toward the east. Again the birds were released well before noon in groups of threes and fives. As in previous experiments the birds carried messages in Army message carriers asking the finder to report when and where the bird was found.

\section{Results}

Table IX lists all birds which were reported (thirty-two percent of total released) up to the present writing. It lists the time and place of release, persons in charge of liberation, time and place they were found, and the distances flown along and at right angles to a line drawn through the conjugate point and the release point.

From racing-pigeon men it has been learned that birds which do not arrive home from oneand two-hundred-mile flights within a few days are likely not to arrive at all. This is taken as an indication that they become discouraged or fly at random after that time. For this reason all birds reported more than ten days after liberation were listed separately (Group B, Table IX) and this data used in a subsequent calculation to test its effect on the more reliable early data. A second separate listing consists of birds which never left, or perhaps returned to the release areas (Group C, Table IX). In any case, they were reported found within a ten-mile radius of the release point. The complete listing of the birds on Table IX is as follows:

Group A-Birds reported within a nine- or ten-day period after liberation.

Group B--Birds reported after June 26th.

Group C-Birds which were reported less than ten miles from the release point.

In working out and interpreting the data of this experiment the same plan was followed as with the previous ones. The flight (release point to flight terminal) of each bird was plotted and a straight line drawn from the release point to the conjugate point. The algebraic sums $\Sigma X$ and $\Sigma Y$ of the components of all the flights toward and at right angles to the theoretically required direction line were divided by the number of birds and added vectorily to obtain the "total flight vector" for the groups.

On Table $\mathrm{X}$ is shown the average angle of deviation obtained from the flight data of the birds listed in Table IX. Those of Group A show a counter-clockwise deviation of $5.8^{\circ}$. When the data from those reported later (Group B) are used in the computations, the average deviation is seen to be +13.5 degrees.

As in the case of the 1944 Kearney experiments, the experimental birds seemed to behave 





according to the magnetic vertical-Coriolis theory by flying on the average, with only small deviation from a line toward the computed conjugate point. It is noteworthy that the angle of deviation for the birds reported within reasonable time limits is extremely small $\left(5.8^{\circ}\right)$, and this in spite of the fact the birds were trained in a manner devised to confuse them if possible. If the training flights around State College, Pennsylvania, had misled them into flying toward the sun or the south-eastern sky each day, then in the Nebraska liberations they would have flown toward the state of Missouri. This would have been roughly ninety degrees from both State College, Pennsylvania, and Kearney, Nebraska, directions.

During the study and computation of the data in this report it was noticed that the pigeons supplied by the Army Signal Corps, on the average, made more accurate flights in the direction of the conjugate point than those obtained from private sources. It therefore seemed desirable that a separate computation be made for these birds. The summation of their flight components $(\Sigma X, \Sigma Y)$ and average components $(\Sigma X /$ No. birds, $\Sigma Y /$ No. birds) are:

Algebraic sum of distance flown in the direction of the conjugate by the twenty Army birds reported up to June $26, \Sigma X=2664$ miles.

Algebraic sum of distance flown at right angles to the above direction, $\Sigma Y=-45$ miles.

As indicated on Table XI, this represents an average flight of 133.2 miles in the $X$ direction and 2.2 miles in the $-Y$ direction or a deviation of only one degree from the average direct line to the conjugate point. This seems to indicate that the Army birds are superior navigators. The small angle of deviation also seems remarkable in view of the flatness of the Nebraska country as contrasted with the mountains in Pennsylvania where the birds were trained, and the anomalous set-up of the earth's magnetic field through which they had to fly in both regions.

\section{REMARKS}

The fundamental importance of the foregoing explanation of the long mysterious bird navigation problem and the experimental data obtained is fourfold :
1. The results furnish an experimental indication that a bird moving across a magnetic field experiences an awareness to the effect.

2. The age-old mystery of bird migrations may be clarified by the results of this and already planned future experiments with wild birds. The ability of the Golden Plover ${ }^{18}$ to navigate from Hawaii to Alaska, 3000 miles one way over ocean vastness, may possibly have an explanation in the homing pigeon's technique.

3. The biologists and psychologists can make use of its findings in studying the effect of a moving magnetic field on living nerves, an effect lacking demonstration up to now. Part of the ills occurring to pilots in super-speed planes and other high velocity craft, and attributed entirely to large values of acceleration, may conceivably be due to moving rapidly through the earth's magnetic field.

4. There is evidence that wild birds and homing pigeons become confused when in the region of powerful broadcasting stations. Although there is much controversy on the subject, the evidence included in this report, both from the standpoint of the magnetic wing and the conjugate point experiments, indicates that the phenomenon could exist. Further evidence of this is also being sought with new experiments on homing pigeons. now under way at The Pennsylvania State College.

\section{ACKNOWLEDGMENTS}

The experimental work has been supported by : the Department of Physics and The Department of Zoology and Entomology of The Pennsylvania State College; the Pennsylvania Wildlife Research Group at The Pennsylvania State College and the Army Service Forces of the United States Army Signal Corps.

The men mainly responsible for carrying out the experimental procedures are: Dr. H. L. Yeagley, Department of Physics, and Professor Merrill Wood, Department of Zoology, both at The Pennsylvania State College; Dr. P. F. English and Dr. Logan Bennett, both of the Pennsylvania Wildlife Research Unit; Dr. George Hendrickson, Associate Professor of Wildlife Management, Iowa State College, and Major

\footnotetext{
${ }^{18}$ F. C. Lincoln, The Migration of American Birds, p. 54.
} 
Otto Meyer, in charge of the Pigeon Service Agency, Army Service Forces, U. S. Army Signal Corps, during World War II.

Note: Illustrative maps and tables are the same as those used in the Reports to the Army Service Forces.

\section{BIBLIOGRAPHY}

G. C. Aymar, Bird Flight (Garden City Publishing Company, Garden City, New York, 1935), p. 99.

C. E. Brown, "Homing pigeons exposed to radio frequency waves," Sci. Am. 160, 45 (1939).

J. E. Brown, "The pigeon cooker," Radio News (April 1938).

J. Casamajor, "The mysterious 'seris de L'espace," " Rev. Sci., Paris, 65, 555 (1927).

E. Chamberlain, The Homing Pigeon (The Homing Pigeon Publishing Company, Manchester, England, 1907).

R. D. Chard, "Visual acuity in the pigeon," J. Exper. Psychol. 24, 588 (1939).

H. E. Dodge, "The racing homer," Feathered World, London, (1922).

M. E. Duchatel, "Faculté de direction du pigeon voyageur," Ann. de Psychol. Zool. 1, 22 (1901).

S. Exner, "Negative Versuchsergebnisse über das Orientierungsvermögen der Brieftauben," Sitz. Wien Akad. Wiss. 101, 318 (1893).

Experiments with homing pigeons sensitivity to radio frequency waves, conducted by 285 th Signal Pigeon Company, March 1945.

D. S. Farner, "The return of robins to their birthplaces," Bird Banding 16(3), 81 (July 1945).

Dr. D. R. Griffin, "The Sensory Basis of Bird Navigation," The Quarterly Review of Biology, 19, 1 (March 1944), pp. 15-31.

R. H. Gundlach, "A field study of høming in pigeons," J. Compar. Psychology. 13, 397 (1932).

R. H. Gundlach, "A test of 'directional sense' in cats and pigeons," J. Compar. Psychol. 12, 347 (1931).

J. Huie, "Orientation," Homing Pigeon 3, 20 (1881). (Reprinted from J. Horticult.)

G. Ising, "The physical possibility of a biological sense of orientation based on the rotation of the earth," Ar. Math. Astrophys, 32A, No. 4 (1946).
Kingsley, "Orientation by inherited memory," Nature, 18 (June 1869).

Fredrick C. Lincoln, The Migration of American Birds (Doubleday Doran and Company, Inc., Garden City, New York, 1936).

W. M. Levi, The Pigeon (R. L. Bryan Co., Columbia, South Carolina. 1941).

O. H. Mowrer, "The nsytagmic response of the pigeon to constant angular acceleration at liminal and supraliminal intensities," Jour. Compar. Psychol. 19, 177 (1935).

F. M. Packard, "The return of young robins to their birthplaces," Bird Banding 18(1), 30 (January 1947).

J. L. Peters, Check-list of Birds of the World (Harvard University Press, Cambridge, Massachusetts, 1931), Vol. 1 or 2; ibid., Vol. 2, 1937; ibid., Vol. 3, 1940; ibid., Vol. 4.

E. S. Starr, "Homing pigeons," Cent. Illust. Month. Mag. 31, 361 (July 1886).

R. M. Strong, "On the olfactory organs and the sense of smell in birds," J. of Morphol. 22, 619 (1911).

F. J. Sauerteig, "Indianapolis," American Racing Pigeon News, November 1942, p. 1.

G. Reynaud, "The laws of orientation among animals," Smith, Inst. Ann. Report of Board of Directors, p. 481 (translated from Rev. des Deux Mondes 146) 380 (1898), also O. H. Mowrer, J. Compar. Psychol. 19, 177 (1935).

W. H. Thorpe and D. H. Wilkinson, "Ising's theory of bird orientation," Nature, December 21 (1946).

A. Thauzies, "L'orientation," Rev. Sci. 9 (series 4), 392 (1898).

A. Thauzies, "L'orientation du pigeon voyageur: donnes experimentales," Rev. Sci. 2 (series 5), 417, 453 (1904).

C. Viguier, "Le sense de l'orientation," Rev. Phil. 14, $1-36(1882)$.

G. J. Van Oordt, Bird Migration (Vogeltrek) (E. J. Brill) Leiden, Netherlands, 1944); Review in Bird Banding, 18 (1), 48 (1947).

J. B. Watson, "Recent experiments with homing birds," Harper's Month. Mag., 457 (May 1913).

J. B. Watson, and K. S. Lashley, "An historical and experimental study of homing," J. Carnegie Inst. of Washington (1915).

A. G. Webster, Dynamics (G. E. Stechart and Company, New York), second edition, pp. 320-322.

$\mathrm{K}$. Wodzicki, et al., "Experiments on homing in birds," Nature, 35 (Jan. 1, 1938). 